\title{
TOWARDS AN INTERCIVILIZATIONAL APPROACH TO HUMAN RIGHTS
}

\author{
For universalization of human rights through overcoming of a \\ westcentric notion of human rights
}

Onuma Yasuaki*

\section{INTRODUCTION}

The problem of human rights has been an enduring object of fierce international controversy. Are human rights universal, or relative to some culture? Should developing nations first pursue economic development, to be followed by the realization of human rights? ${ }^{1}$ Or should they pursue the latter from the beginning even at the alleged cost of economic development and political stability? This presentation of human rights as a problem reflects fundamental issues which will continue for many decades.

These issues involve (1) conflicts between the transnationalization of economic and informational activities and the sovereign states system; (2) conflicts between the global quest for human dignity and the grudges held by developing nations against the past imperial policies of today's developed nations and

\footnotetext{
"University of Tokyo. This paper is a summary of the author's book Jinken, kokka, bunmei [Human rights, states and civilizations] (Tokyo: Chikuma Sobo, 1998). A shorter version of the article was published in J. BAUER and D. BELl (eds.), The East Asian Challenge for Human Rights (Cambridge, 1998). The author owes a debt of gratitude to many people. First, to Pro-

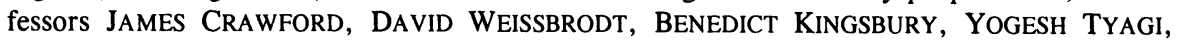
AMARTYa SEN, DANIEl Bell and JACK DONNELly, for reading an earlier manuscript and giving critical comments. Second, to the Asia Foundation, the Carnegie Council on Ethics and International Affairs and the Japan Institute of International Affairs, for inviting the author to a number of workshops where he could exchange views with leading scholars and activists of human rights. Third, to his proofreaders for correcting and improving his English. Finally, to Professor Teraya Koji, Messrs. Kawazoe ReI and Saito Tamito, Ms. Oshima MaKiKo and other graduate students of Tokyo University who assisted him in checking references. Especially, without the devotion of Mr SAITO the author could not have finished this contribution. The author regrets that, due to the limited time available for the proofreading, the updating of data and references in view of the lapse of time since the writing of the manuscript could only be realized partially.

'Here, the term 'human rights' connotes only civil and political rights, ignoring economic, social and cultural rights. The problematic nature of this predominant usage of 'human rights' will be fully discussed later.
}

Asian Yearbook of International Law, Volume 7 (Ko Swan Sik et al., eds.

- Kluwer Law International; printed in the Netherlands), pp. 21-81 
against the huge economic gaps between the former and the latter; and (3) conflicts between East Asian ${ }^{2}$ nations as economic powers and the Westcentric ${ }^{3}$ structures of international information and culture. These fundamental problems require us to deal with the question of human rights not merely as a current visible issue. What is needed is a comprehensive framework within which issues of human rights can be understood as the expression of these fundamental problems. This paper seeks to present, albeit in an abstract and incomplete manner, such a framework.

\section{CONFLICTS DESTABILIZING THE INTERNATIONAL ORDER AND THE NEED FOR AN INTERCIVILIZATIONAL APPROACH}

\subsection{The conflict between the transnationalization of economics and information and the sovereign states system}

Post-war economic activities have been generated and supported by incessant technological innovation, the internationally predominant capitalist economy and peace among developed countries lasting half a century. Together with these economic activities, informational activities have also expanded their spheres on a global scale. Media institutions of developed countries constantly send global news to their citizens in a sensational manner. This news, especially if sent into the living rooms of ordinary citizens in developed societies on television, is often shocking to them, reflecting huge differences in economic situations, political regimes, religions and social customs between developed countries and developing countries. To those whose per capita national income is over US\$20,000 and whose life expectancy is nearly eighty years, the 'price of life' of those whose per capita income is less than US\$ 500 and whose life expectancy is approximately fifty years can appear extremely cheap. Political persecutions, the inhumane treatment of prisoners and apparent discriminatory practices are all vividly depicted on TV screens. This invites anger against the offenders and sympathy with the victims.

However, today's international society is based on the sovereign nation states system, the fundamental principles of which include the equality and the independence of states. The principle of non-intervention, though challenged in many respects, is a fundamental principle of current international law. The Declaration on Principles of International Law concerning Friendly Relations

\footnotetext{
In this article, 'East Asia' is used in the broader sense of the term, i.e., including North East and South East Asia.

' 'Eurocentrism' is generally used to designate a tendency to approach natural and social phenomena from a perspective which assumes the West European and North American way of thinking as the standard framework. However, it is not only the West European , but also - or rather - the US way, that is decisively influential in today's world. This is why the term 'Westcentrism' will be used here rather than 'Eurocentrism'.
} 
and Co-operation among States in Accordance with the Charter of the United Nations of 1970 expresses far-reaching obligations of non-intervention by providing that "[n]o State or group of States has the right to intervene, directly or indirectly, for any reason whatever, in the internal and external affairs of any other State. Consequently, armed intervention and all other forms of interference or attempted threats against the personality of the State or against its political, economic and cultural elements, are in violation of international law".. There are other resolutions of the United Nations and other international organizations or conferences to similar effect. ${ }^{5}$

Although the sovereign states system is becoming obsolete from the perspective of the global economy and information, it will most likely survive for the foreseeable future. This is evident especially in the field of security. For many developing countries, which comprise various linguistic, religious or ethnic groups struggling with each other, the case will be even more than a mere survival of the system. For them, the coming decades will be nothing less than an era of nation-building, overcoming domestic conflicts and consolidating the state mechanism.

Thus, the twenty-first century will witness conflicting developments. On one hand, the sovereign states system will be gradually eroded by the constantly expanding and penetrating global economy and information. Although this global economy and information is managed mainly by developed countries, or, more precisely, their corporations and regulators, it will penetrate developing countries as well. On the other hand, the sovereign states system will be adhered to and actually consolidated by many developing countries. ${ }^{6}$ This conflict will pose a serious problem to human beings in the twenty-first century. It may become even more serious in combination with the second conflict as discussed in the following section.

\subsection{The conflict between the global quest for human dignity and the sense of victimization on the part of developing nations}

In developed societies, where people generally enjoy a high standard of living, the quest for economic well-being no longer occupies such a high priority as it used to. Instead, a quest for human rights (understood mainly as civil and political rights), and a more recent demand for environmental protection are attracting more and more people. Accordingly; the voice becomes stronger of those who claim that they should not tolerate serious human rights violations

\footnotetext{
A/RES/2625 (XXV), GAOR 25th Sess., Suppl.No.28 (A/8028)[1970].

${ }^{5}$ A/RES/2131(XX), GAOR 20th Sess., Suppl.No.14 (A/6014)[1965]; A/RES/36/103, GAOR 36th Sess., Suppl.No.51 (A/36/51)[1981].

'ONUMA YASUAKI, Wakoku to kyokuto no aida [Between the country of ' $\mathrm{Wa}$ ' and the 'Far East'] (Tokyo, 1988) 192-203.
} 
- or massive environmental degradation - even if committed in foreign countries. These persons demand their government to intervene in the delinquent state and stop serious human rights violations. This phenomenon, typical in the US today, can also be witnessed in other developed societies. It will continue to spread.

However, most of the nations where serious violations of human rights occur and which are targeted] for criticism were once under colonial rule. Moreover, they have suffered from military intervention, or have been economically exploited by developed countries. Because of this humiliating past, they tend to respond to criticism by the developed countries in an excessively sensitive manner. For those who have experienced colonial rule and interventions under such slogans as 'humanity' or 'civilization', 'the term 'human rights' often sounds nothing more than another beautiful slogan by which great powers have rationalized their interventionist policies. ${ }^{8}$

To say that such a claim is a convenient excuse of the leaders of authoritarian regimes to evade criticism of their oppressive policies is certainly true, at least in part. No nation is monolithic. Even in countries which do not respect freedom of expression, one can hear dissenting voices criticizing the formal view of the ruling party or the government. It is necessary to encourage such voices. However, can we say that in these countries it is the voice of such dissenting activists, not the view of the government, that represents the people as a whole? Not necessarily. Herein lies a difficult problem.

It is true that the Chinese Communist Party, the Vietnamese Communist Party, the government of Singapore and some other Asian regimes suppress the voice of certain citizens who demand respect for freedom. It is not likely that these suppressive regimes can be maintained indefinitely in their present form. The desires of many people seeking more freedom will bring about political regimes which respect more freedoms than today. However, these facts and expectations do not necessarily mean that the present regimes have not represented the will of the people. It is in fact less certain that in these countries human rights activists represent the will of the people as a whole. Unlike the socialist regimes in Eastern Europe, these regimes were not imposed by an outside power, the USSR. Most of them grew spontaneously from struggles

\footnotetext{
'The idea of 'mission civilisatrice' was utilized by the Western powers to rationalize imperialist policies. The idea of 'humanitarian intervention' was resorted to frequently by them, e.g. when they militarily intervened in Turkey, Rumania and other 'uncivilized' nations. See J. KUNZ, 'Zum Begriff der 'nation civilisée' im modernen Völkerrecht', 7 Zeitschrift für öffentliches Recht (1928) 89-95; TABATA S., Jinken to kohosaiho [Human rights and international law] (Tokyo,1952) 41-48; G. SCHWARZENBERGER, 'The standard of civilisation in international law', Current Legal Problems (1955) 220-22; G. GoNG, The standard of 'civilization' in international society (Oxford, 1984) 45-53, 76-81 et passim.

${ }^{8}$ See, e.g., DING Y., 'Opposing interference in other countries' internal affairs through human rights', 41 Beijing Review (Oct.1989) 10-12. LANG Y., 'Shehuizhuyi shehui de renquan shijian yu guoji renquan douzheng' [Implementation of human rights in socialist countries and international struggles for human rights], Qiushi Zazhi 1991-2 (1992) 10-15.
} 
against colonial rule, interventions by imperial powers, poverty, and privileged ruling classes of the past. Despite many shortcomings such as authoritarian rule, corruption, and violations of human rights, they were chosen (in the broader sense of the term) by their own people to fight the violence and misery of the past. As such, they have a certain legitimacy. Moreover, for these nations overcoming domestic conflicts in the course of nation-building is a vital task. While most of today's developed countries have already completed this task in a violent manner up to the early twentieth century, for most developing countries it is the task of today and tomorrow.

Given these facts, it is too simplistic to assert that the claims of the governments of these countries merely aim at rationalizing human rights violations. It is rather self-complacent to say that the voice of human rights activists represents the true will of their people. Resistance to the criticism by developed countries, whether by their governments or NGOs, is not limited to the ruling elite. When the Chinese government is criticized for its human rights violations, it often tries to offset the criticism by referring to imperialistic policies by the Western powers and Japan since the Opium War. It is true that these are 'diplomatic cards' against the Western nations and Japan. However, it is because historical facts of Western imperialism and Japanese aggression do exist, as does a deeply rooted rancor among Chinese people, that the Chinese leaders can use these diplomatic cards. Such rancor, grudges and animosities against colonial rule, intervention, economic exploitation, racial discrimination, and religious prejudice by the once imperial, now developed, nations are widely shared by people in many developing countries. In such situations, 'human rights diplomacy' or criticism by NGOs in developed countries are likely to be perceived as arrogant interventions or pressures. Hence, even legitimate criticism often can not fulfill its proper task of improving human rights conditions.

\subsection{Emerging discrepancies between economic power and intellectual/ informational hegemony in international society}

The problem described above is closely related to the third problem, that of emerging discrepancies between the economic power of East Asian nations and the intellectual and informational hegemony of Western nations, especially the US. In the early 1990s, the controversy over the universality vs. relativity of human rights was fiercely contested between Western nations, particularly the US, and some East Asian nations such as China, Singapore and Malaysia. This can be seen as a symptom of those discrepancies which will become increasingly problematic in the twenty-first century.

In the twentieth century the US has had a tremendous influence upon the ways of thinking and behavior of people around the world. It spread its ideas and images on humans, societies and the universe by various means: English as the 'lingua franca' of the world; influential media institutions represented by 
CNN, the AP and the New York Times; powerful popular cultures represented by Hollywood movies and popular music; and many other informational, educational and cultural institutions. ${ }^{9}$ In the early twenty-first century, when 'democratization' and 'marketization' make progress in developing countries, the Americanization of society will again prevail. The US's 'soft' power resources ${ }^{10}$ which define, orient and influence people's way of thinking are likely to become even stronger on a global scale.

On the other hand, many East Asian nations have achieved economic development and social stability in the latter half of the twentieth century. Japan is already on a par with the US and Western European countries in terms of human development indices, and Taiwan, Singapore and South Korea are catching up. These nations have generally achieved a more equitable distribution of wealth, and enjoy a better situation in terms of crime or narcotics than the US and many West European countries. For example, in terms of income share the ratio of the highest $20 \%$ to the lowest $20 \%$ is 3.4 in Japan, 5.2 in South Korea, 4.7 in Germany, 5.6 in France, 8.9 in the US, and 9.6 in Singapore (1980-94 for Singapore, and 1987-98 for the rest). ${ }^{11}$ The number of homicide cases per 100,000 people from 1995 to 1997 is 1.0 in Japan, 3.6-4.4 in France and 6.88.2 in the US. ${ }^{12}$ Other indices in criminal cases basically indicate similar tendencies. China is likely to become one of the largest economic powers in the twenty-first century. Although these increases in power, economic prosperity and social stability of East Asian nations are in many ways based on the introduction of Western ideas and institutions, they are also based on their own cultural heritage and social underpinnings. It is natural for these nations to become more confident in their own ways, and more critical of the self-righteous and assertive ways of Western, particularly US, diplomacy and the activities of Western NGOs.

However, as far as the problem involves human rights, we should not end the discussion by saying that it is natural for East Asian nations to be critical of Western, especially US, self-righteousness. Few would deny the importance of the prohibition of torture. Few would tolerate people dying from starvation. Differences in culture or religion, and the principle of non-intervention under

\footnotetext{
As to this influence, see, e.g., E. SAID, Orientalism (New York,1979); M. FEATHERSTONE (ed.), Global culture (London,1990); J. NYE, Bound to lead (New York,1990) 188-201; J. TOMLINSON, Cultural imperialism (London, 1991).

${ }^{16}$ NYE, ibid. at 188.

" UNDP, Human Development Report 1999 (Oxford,1999) 146; UNDP, Human Development Report 2000 (Oxford,2000) 172.

"Homu Sogo KenKyujo, Hanzai hakusho heisei 11 nen han [Criminal White Papers] (Tokyo, 1997) 26.
} 
international law are not a licence for the violation of human rights. ${ }^{13}$ Nonetheless, if those critical of such violations and looking from the outside are ignorant of religions, cultures and social customs in the communities concerned, and lack self-criticism of their own behaviour, their criticism may be regarded as arrogant intervention by external powers. Consequently, we must explore ways to overcome these dilemmas.

\subsection{The need for an intercivilizational approach to human rights}

The foregoing analysis indicates that we should not regard the increased interest in human rights merely as an intellectual fashion arising out of some visible changes, such as the end of the Cold War. Nor should we confine this interest within the controversy over the universality vs. relativity of human rights. We need a more comprehensive and longer-term perspective on human rights.

On one hand, the mechanism of human rights has brought about tremendous benefit to a large number of people by protecting their vital interests in the modern era of sovereign states and capitalism. It will bring about the same profit to an even larger number of people in the process of modernization in developing countries. On the other hand, many of these countries have legitimate reasons for resisting the imposition of human rights from the outside. Conflicts between the spread of human rights and local cultures which are alien to individualism and legalism will pose another problem. Furthermore, the mechanism of human rights is the historical product of a specific time and place, with its own historical qualifications. One of the major counterarguments raised by some East Asians against Western human rights advocates is that contemporary developed societies, especially the US, are suffering from various social diseases such as crimes, drugs, and the degradation of family and community ethics. They argue that these diseases may well be a consequence of excessive legalism ${ }^{14}$ and individual-centrism, ${ }^{15}$ which are major components of the idea of human rights.

\footnotetext{
13 As to human rights and the plea of domestic jurisdiction, see L.HENKIN, 'Human rights and domestic jurisdiction', in T. BUERGENTHAL (ed.), Human rights, international law and the Helsinki Accord (Washington,1977) 21-40; A.CASSESE, 'The General Assembly: historical perspective 1945-1989', in P.ALSTON (ed.), The United Nations and human rights (Oxford,1992) 28-29, 32-34, 43-44, 50; ONUMA YASUAKI, Jinken, kokka, bunmei [Human rights, states and civilizations](Tokyo,1998) 77-138.

${ }^{14}$ Here legalism means a way of thinking whereby members of a society think highly of law and legal enforcement mechanisms for societal values, and their behavior is highly influenced by such ideas as 'law', 'rights', 'justice' and 'juridically enforced realization of values'. See also J. SHKLAR, Legalism (Cambridge, Mass. 1964).
} 
The mechanism of human rights has developed hand in hand with the development of individual-centrism and the establishment of legal mechanisms stressing the importance of rights. ${ }^{16}$ Until recently, a modernist framework which sees only the positive aspects of this development of modernity has been predominant. The more individualistic a person becomes, the more liberated he or she is from various constraints such as the institution of the family, feudalistic ties, rural communities and religious authorities. The more firmly a legal mechanism is established to protect citizens from the power of states, the more secure their values and interests will become. Although such a naive modernist perception is no longer held by many experts in developed societies, it is still strong among the masses, and even among intellectuals in non-Western societies, because of a persistent image of the 'developed, right-oriented and individualistic West vs. the underdeveloped, non-legalistic and collectivist East'.

Legalization, stressing the importance of rights, and individualization of humans are certainly important and useful in societies where modernization has started only recently. Many developing countries belong to this category. However, no idea or institution is omnipotent. Particularly in societies where modernization has reached a certain stage, negative aspects are also becoming evident. For the last few decades, we have witnessed the emergence of communitarianism and a virtue-oriented philosophy as opposed to the individual-centered and rights-oriented philosophy in the US, where legalism and individualcentrism has been predominant. This phenomenon indicates that reappraisal is needed and has actually begun. We must therefore take a perspective which enables us to evaluate human rights in the long history of humanity, to judge its proper range, and to compare it with other mechanisms pursuing spiritual and material well-being. ${ }^{17}$ We may call this perspective an intercivilizational approach to human rights. This approach requires us to see human rights not

\footnotetext{
${ }^{15}$ Here individual-centrism means a way of thinking whereby members of a society regard highly individuals who are independent from their societies and from the nature surrounding them, and tend to deny the dependence of individuals upon other people, collectivities, and nature. In this context modernization, especially the development of sovereign states and a capitalist economy, has liberated humans from various premodern collectivities, social institutions and superstitions. However, by urging individuals to be independent and autonomous although they are not so strong, it has created various problems of alienation in societies. Although 'individualism' sometimes carries connotations described above, it has equivocal meanings. This is why the term 'individual-centrism' is used here.

${ }^{16}$ As to the importance of 'rights', see C.TAYLOR, 'Human rights', in Philosophical foundations of human rights (UNESCO, Paris,1986) 49 et seq. On the other hand, problematic features of 'rights talk' in the US are vividly depicted by M.GLENDON in Rights talk (New York, 1991).

"As to my view of human rights as a specific formulation of a universal pursuit for the spiritual as well as material well-being, see ONUMA YASUAKI, In quest of intercivilizational human rights (The Asia Foundation's Center for Asian Pacific Affairs, Occasional paper No.2, 1996) esp.8-9, 14 n.4, 15 ns.54 and 55.
} 
solely within the context of Westcentric modern civilization, where it originated, but from other civilizational perspectives as well.

It is true that the 'civilization' has problematic features. It is an ambiguous notion with hundreds of definitions. ${ }^{18}$ There is also a danger of abusing and overestimating the notion of civilization in dealing with international or global affairs ${ }^{19}$ Thus, it might be better to avoid the term and instead to adopt the term 'culture' as a comprehensive analytical concept, defined as a prevailing way of thinking and behavior in a society. There have been remarkable studies utilizing the notion of 'cross-cultural perspectives' in recent years. ${ }^{20}$ These studies in many respects share perspectives with the intercivilizational approach.

However, there are problems in using the term 'culture' as a comprehensive analytical concept. First, in the field of human rights, 'culture' has not been used as a comprehensive notion designating a prevailing way of thinking and behavior in general. Rather, it is used as a narrower concept excluding economic, social, civil and political fields. International instruments on human rights have followed this narrower terminology. Thus, it is difficult to avoid confusion if one uses 'culture' as a comprehensive concept. It would be better to use 'civilization' as a comprehensive concept. Second, 'culture' has also hundreds of definitions and has been abused as an ideological notion. Assertions based on a 'national culture' reveal this danger. Third, there are factors which influence the ways of thinking and the behaviour of certain peoples whose existence transcends national boundaries but does not necessarily cover the entire globe. We may be able to call such a sphere of peoples a 'region'. Such a sphere of peoples has not only a geographical dimension but also a historical duration. It may last long with substantial changes in its characteristic features or may disappear as a distinctive sphere of peoples, while the component peoples themselves continue to live as distinct groups. Such a sphere of peoples with geographical and historical dimension can be most appropriately termed a civilization.

The term is most common, although with variations in such words as 'civilization' in English, 'civilisation' in French and 'Zivilisation' in German, whose meanings are not necessarily identical with each other. Religions, lan-

\footnotetext{
1* See L.Febre et al., Civilisation: le mot et l'idée (Paris,1930); A. KROEBER and C. KLuCKHOHN, Culture: A critical review of concepts and definitions (Cambridge,Mass.,1952); R.KEESING, 'Theories of culture', 3 Annual Review of Anthropology (1974) 73-97. As an example of the equivocal nature of the term 'civilization' see S. HUNTINGTON, infra n.19.

1" Samuel Huntington, in his alarming article 'The clash of civilizations?', Foreign Affairs (Aug. 1993) 22-49, apparently made the mistake of overestimating the role of civilizations in international relations. His subsequent book, The clash of civilizations and the remaking of world order (New York, 1996) basically retains the characteristic features of the article.

2) See A.AN-NA'IM and F.DENG (eds.), Human rights in Africa: cross-cultural perspectives (Washington,D.C.,1990); A.AN-NA'IM (ed.), Human rights in cross-cultural perspectives: a quest for consensus (Philadelphia,1992).
} 
guages, ethics and customs that influence the thoughts and behavior of people transcend national boundaries and are shared within the framework of a civilization. It is true that the term 'international' will continue to be the most important concept for the understanding of various phenomena interrelating or transcending nations. However, the notion of 'inter-civilizational' will be both necessary and useful as a concept which can qualify and complement the international perspective of human rights and other global issues. ${ }^{21}$

A 'transnational' perspective also can qualify and complement an 'international' perspective. Both inter-civilizational (or cross-cultural) and transnational perspectives pay attention to transboundary activities of non-state actors such as individuals, non-profit organizations (NPOs), multinational corporations and masses sharing the same religious or other belief-systems. The transnational perspective has tended to assume that various actors and their activities go beyond the national border and assume global influence. However, most such actors with global influence are concentrated in developed countries. Moreover, individuals, NPOs and companies are all characterized as transnational actors in the same category. Thus, global activities of multinational corporations, which are most influential among them, tend to represent 'transnational' activities and perspectives. In this way, transnational perspectives have often strengthened rather than qualified international perspectives of developed societies.

In contrast, the inter-civilizational perspective pays attention to social beings, activities and characteristics with regional dimensions transcending nations, such as Islamic, Christian, and Confucian civilizations. Therefore, it can analyze and explain global phenomena from a more realistic and balanced point of view. For example, if we pay attention to a group of people who share Islam rather than paying attention to 'individuals', NPOs, or companies, which constitute transnational perspectives, we can see more clearly their actual influence in global law and politics. At a normative level, such views and activities based on diverse civilizations could more effectively qualify or counter-balance the predominant 'international' or 'transnational' perspectives, which are often Westcentric perspectives in disguise.

In order to minimize the ideological abuse of the term 'civilization', it should be used as a functional rather than a substantive notion. Accordingly, a nation need not necessarily belong to one civilization in an exclusive manner. Japan combines characteristic features of Westcentric modern, mass-cultureoriented twentieth century American with Confucian and Buddhist civilizations. The US is the center of mass-culture-oriented twentieth century American civilization, but also embodies characteristic features of Christian and Westcentric modern civilizations. The degree of such 'belonging' to diverse civilizations

\footnotetext{
${ }^{2}$ See my remarks in 'Promoting training and awareness - The task of education in international law', Proc.ASIL 1981 at 163-67; ONUMA, op.cit.n.6 at 20-49.
} 
varies from society to society. It varies even within a particular society according to generations, classes and the like.

The intercivilizational approach is needed not only for human rights but also for other problems related to the three major conflicts described earlier. A special case is China that is likely to become a superpower in the twenty-first century. Except for the last one hundred years China has always regarded itself as the center of the world and had substantial powers to support this egocentric world view. It will be difficult for China, in light of this resurgent Sinocentrism, to swallow the Westcentric (or US-centric) view of the world that we share today. However, the US, another superpower, is also accustomed to regarding itself as the center of the world. For the last fifty years it has been so powerful and prosperous that it believed propagating the American way on a global scale to be both possible and desirable. It will be difficult for the US to give up its egocentric universalist worldview within a short period of time. Hence the danger of direct confrontation between China and the US. To avoid this confrontation, a more pluralistic and longer-term perspective is needed. Sharing an intercivilizational perspective could moderate conflicts between the egocentric universalist perspectives.

\section{PROBLEMS RELATING TO THE UNIVERSALITY VS. RELATIVITY OF HUMAN RIGHTS}

\subsection{The Range of 'Universality' of Human Rights}

Human rights have been defined as the rights which a human has simply because he or she is a human (or human person). ${ }^{22}$ The 'human' in this definition has been required to meet certain qualifications. As suggested in some European languages designating a human (man, homme), in Europe the term was for a long time identified with the male, implicitly excluding woman. It was only after 1945 that the very term 'human rights' became predominant instead of 'rights of man'. In the French language, 'droits de l'homme' rather than 'droits humains' is still largely used today. The propertyless classes and

\footnotetext{
This definition has been adopted by many experts of human rights, especially those in liberal democratic countries. See J. DONNELLY, Universal human rights in theory and practice (London: Ithaca, 1989) 12,49,66; R. HIGGINS, Problems and Process (Oxford,1994) 96, and ASHIBE N., Kempo gaku [A theory of constitution] Vol.2 (Tokyo,1994) 4. However, there are diverse definitions according to national constitutions, ideologies and other factors. See e.g. A.PoLLIS, 'Liberal, socialist, and third world perspectives of human rights', in P.SCHWAB and A.POLLIS (eds.), Toward a human rights framework (New York, 1982) 1-26.
} 
'people of color' were also excluded from enjoying human rights, especially political rights." ${ }^{23}$

The century and a half following the American Declaration of Independence and the French Declaration of the Rights of Man and the Citizen, two of the most famous human rights declarations witnessed the peak of colonization by Western powers. Although in some colonies legal practices improved over time, people under colonial rule were generally denied the rights proclaimed in these Declarations. It was only after the adoption of the Universal Declaration of Human Rights, the successful developments in the field of civil rights for 'people of color' in the US, the worldwide decolonization, as well as the rise of feminist movements, that 'humans' as the alleged bearers of human rights gradually came to lessen the barriers of sex, property, race, religion and other qualifications in a substantial manner.

Despite, or rather because of, these implicit qualifications, human rights were alleged to be based on an abstract humanity. 'Humans' thus implicitly qualified were homogeneous - 'white' men of the propertied classes, mostly Christians - and could be regarded equal within this homogeneity. Although in a pseudo- and self-deceptive manner, 'universality' was thus warranted in the mainstream discourse on human rights. Few dared to question the exclusion of women and 'people of color' from the term 'humans'. Even if some raised the issue, their claim was either ignored or effectively defeated by dominant forces such as men or 'whites'. ${ }^{24}$

However, since human rights are defined simply as rights based on humanity, it was inevitable that those implicitly excluded from the rights would claim entitlement to these rights as well. It was difficult to deny the legitimacy of this claim, precisely because the rights were defined as 'human' rights. It is true that the male-dominated French National Assembly of 1792 denied the Declaration of the Rights of Women, and that the Westcentric Versailles Conference of 1919 rejected the Japanese proposal for including a racial equality clause in the Covenant of the League of Nations. ${ }^{25}$ However, these denials were finally rectified. The 1948 Universal Declaration of Human Rights and the two 1966 International Covenants on Human Rights accepted the equality of sex and race in a clear and explicit manner. Contemporary international society is still making various efforts to substantiate the provisions of these instruments.

In this way the history of human rights indicates that the idea of human rights, despite its ideological nature of protecting the interests of a limited group of bearers, constantly sought to overcome, and did gradually overcome, at least to a certain extent, its limitations. Like other ideas characterized as uni-

\footnotetext{
H.VON SENGER, 'From the limited to the universal concept of human rights', in W.SCHMALE (ed.), Human rights and cultural diversity (Golbach, 1993) 52-66.

${ }^{24}$ Ibid. 53-79.

35 Ibid. 54-55, 66-79; ONUMA YASUAKI, 'Harukanaru jinshu byodo no riso' [The unreachable ideal of racial equality], in ONUMA YASUAKI (ed.), Kokusai ho, kokusai rengo to nihon [International law, the United Nations and Japan](Tokyo, 1987) 447-56.
} 
versal, the strength of the idea of human rights lies in this universalizing power. Controversies over universality vs. relativity in the 1990 s were a consequence as well as a part of this historical dynamism. ${ }^{26}$ Seen from this longerterm perspective, we should note certain contradictions in these controversies.

\subsection{Contradictions in the Universality vs. Relativity Controversies of the 1990s}

\subsubsection{Reversals in the position of western and non-western nations}

The 'universality' of human rights, as suggested by the history described above, was claimed by 'the people of color' who had been alienated from enjoying human rights. Western powers in contrast were inclined to deny the universal nature of human rights by resorting to differences in religion, culture, or social customs. Today, the anti-universalist arguments based on cultural or religious differences are raised by many leaders of Asia and Africa. ${ }^{27}$ In contrast, it is now the Western powers that assert the universality of human rights. One can thus see a radical reversal of positions on both sides.

Similar changes can be seen in the attitude of states toward the international mechanism for the protection of human rights. Today, the US government loudly voices the high cause of human rights. The US Congress and government, however, were reluctant to establish an effective mechanism for human rights in the UN at its inception. The Congress was extraordinarily cautious of 'interventions' by international organizations in US domestic questions. The US government was concerned that race problems in the US might be taken up in the UN. Other major powers such as the USSR and the UK were equally reluctant to establish an effective mechanism for human rights. It was govern-

\footnotetext{
${ }^{26}$ Marxists have criticized the notion of human rights as nothing more than an ideology masking the domination of the bourgeois class over the proletarian class. Freedom of expression, e.g., existed merely on paper for those without effective means of propagating their opinions. Today, this criticism is less effective in developed countries, many of which distribute a certain portion of economic prosperity to the working class. But it is still valid in most developing countries, where huge gaps between the rich and the poor prevent not only the realization of economic and social rights but also effective guarantees of civil and political rights. For the mechanism of human rights to respond to this criticism, it must overcome the absolute poverty and the huge gaps between the rich and the poor in these countries.

See, e.g., the argument employed by LEE KUAN YEW, one of the most eloquent critics of the universal notion of human rights: F.ZAKARIA, 'Culture is destiny - a conversation with Lee Kuan Yew',73 Foreign Affairs (1994) 109-26. See also A.POLliS and P.SCHWAB, 'Human rights: A western construct with limited applicability', in SCHWAB and POLLIS (eds.), Human rights: cultural and ideological perspectives (New York, 1979) 1-18; S. SiNHA, 'Human rights: a non-western viewpoint', 67 Archiv für Rechts-und Sozialphilosophie (1981) 76-91; B. KAUSIKAN, 'Asia's different standard', 92 Foreign Policy (1993) 24-41.
} 
ments of smaller nations such as Panama and Cuba as well as NGOs that were eager to strengthen the mechanism. They contributed to the improvement of the Dumbarton Oaks Proposals, which contained only a poor provision on human rights. ${ }^{28}$

For three decades after the establishment of the United Nations, the US was reluctant to strengthen the mechanism for the protection of human rights. Although the UN Human Rights Commission received thousands of petitions to deal with concrete violations of human rights, it refused to take up these petitions until as late as the late 1960s. A major reason for this negative attitude was the reluctance of the major powers, especially the US. The latter was also extremely reluctant to ratify the 1966 International Covenants on Human Rights and other human rights treaties. The atmosphere in the US Congress at the time was so strongly against human rights treaties that the EISENHOWER administration promised that it would not ratify them. Only as late as 1992 did the US ratify the ICCPR (as compared with most other developed countries which had ratified during the 1970s), with reservations, understandings and declarations substantially nullifying its effect. ${ }^{29}$

The 1965 International Convention on the Elimination of All Forms of Racial Discrimination for the first time established a monitoring body: the Committee on the Elimination of Racial Discrimination. The Committee began to deal with concrete cases of human rights violations in terms of racial discrimination. The ECOSOC adopted Resolutions 1235 and 1503 in 1967 and 1970 respectively, enabling the UN Human Rights Commission to deal with specific cases of human rights violations. Developing countries and socialist countries, rather than Western nations, brought about these changes. They sought to strengthen the human rights mechanism, though mainly to attack 'apartheid' South Africa, Palestine-occupying Israel, and PINOCHET's Chile. They became less enthusiastic with or even hostile to such mechanism when it took up human rights violations of their own. ${ }^{30}$

These examples reveal the highly ideological nature of human rights. Like the notions of humanity, equality, freedom, or democracy, human rights is an attractive term which few can deny. Therefore, governments or politicians have abused it to attack their opponents by labeling them violators of human rights or characterizing themselves as standard-bearers of these rights. However, because it is defined as 'human' rights, not 'bourgeois', 'white', 'male' or

\footnotetext{
2s See J.BURgers, 'The road to San Francisco', 14 Human Rights Quarterly (1992) 475-77; NISHIZAKI F., 'Sekai jinken sengen to Amerika gaiko' [The Universal Declaration on Human Rights and US diplomacy], in ARUGA T.(ed.), Amerika goiko to jinken [Human rights and US foreign policy] (Tokyo, 1992) 37-65, esp. 41-42, 47-48, 54.

2 N.KAUFMAN and D.WHITEMAN, 'Opposition to human rights treaties in the United States Senate', 10 Human Rights Quarterly (1988) 309-37; D.FORSYTHE, 'Human rights in US foreign policy', 105 Political Science Quarterly (1990) 436-43; T.EVANS, US hegemony and the Project of Universal Human Rights (London, 1996) 105-18.

30 P.ALSTON, 'The Commission on Human Rights', in op.cit.n.13 at 141-44, 145-81.
} 
'Christian' rights, the notion of human rights can recoil on those who abuse it for political purposes. Therefore, the above examples need not necessarily lead to cynicism about human rights. Rather, they can be, and should be a basis for further universalization. States that once have asserted human rights for whatever reason can be demanded to abide by these rights themselves because of their essential feature of universal applicability. For example, the US government has severely attacked human rights violations by the governments of socialist and developing countries. Although the US government tackled its racial problem mainly for domestic reasons, there was a concern in the US government to respond to the criticism of hypocrisy. ${ }^{31}$ Similar examples can be found in many countries.

\subsubsection{Problematics of the theory of the universal origin of human rights}

It has been frequently asked whether human rights were solely of European origin, or existed in other regions as well. Some intellectuals in developing countries criticize the universalist discourse of human rights by the West, yet claim that human rights have been known in their own civilization, religion or culture since ancient times (one may call this a 'theory of universal origin'). ${ }^{32}$ This view is often shared by intellectuals in developed countries. Why has this question been repeatedly asked and answered in the affirmative? Aside from a passing interest among Western intellectuals as to whether human rights existed in non-Western societies, there are the following factors to bear in mind.

First, one should consider various unfavourable factors surrounding intellectuals or human rights advocates in many non-Western societies. The term 'human rights' invites certain suspicions and antipathies from the government, the military, religious leaders or influential persons in local communities. It is still alien to a majority of the population. Under these circumstances, it is understandable for intellectuals or human rights advocates in those societies to argue: "Look, human rights are not alien. They are already present in the teaching of our religion (culture, customs, etc.)". In order to propagate the idea of human rights in non-Western societies, it is thus generally both useful and effective to resort to the theory of universal origin.

Second, many non-Western intellectuals are critical of Westcentrism which has spread an image that anything good in human history originates in the West. The notion of human rights is one of these historical products characterized as good, and therefore must have originated in the West. Some non-

\footnotetext{
See SEkIBA C., 'Tiaso seisaku to jinken mondai' [US Diplomacy towards the USSR and human rights], in ARUGA, op.cit.n.28, and NISHIZAKI, ibid.

"See, e.g., M.NAWAZ, 'The concept of human rights in islamic law', 11 Howard Law Journal (1965) 325-32; Y.TYAGI, 'Third world response to human rights', 21 IJIL (1981) 119-40; Y. KHUSHALANI, 'Human rights in Asia and Africa', in F.SNYDER and S.SATHIRATHAI (eds.), Third World attitudes toward international law (Dordrecht, 1987) 321-34.
} 
Western intellectuals have tried to challenge such a false way of thinking. If such good thing as human rights existed in Europe, they argue, it should also have existed in their own culture or religion..$^{33}$ There is a psychological background to this argument. The pride of intellectuals in many developing countries is hurt by today's realities surrounding them, such as poverty, dictatorship and corruption. Under such circumstances, it is understandable that some make rather self-contradictory arguments, severely criticizing Westcentric universalist discourse of human rights, yet claiming that human rights - something good - once existed - albeit not fully existing today - in their own cultures or civilizations.

Third, there is an element of guilt-consciousness on the part of certain intellectuals in developed countries. While they are generally critical of human rights violations in developing countries, at least some of them, whether consciously or unconsciously, feel guilty of, or at least concerned, about the wide gap between the affluent North and the poor South, their nations' past colonial rule, and their resource-consuming life styles. They are also sensitive to the criticism of Eurocentrism. For them, it is somewhat difficult to assert that human rights (something good!) existed exclusively in Europe. Nodding to the assertion that human rights existed in Islam, Hinduism, Confucianism, etc. is much easier than refuting it.

Fourth, many intellectuals have been committed to securing acceptance of the idea of human rights on a global scale. They have engaged in a project of common myth-making, establishing a history of universal human rights deriving from various religions, cultures and civilizations, in order to bring universal human rights into being. In this way, both developed countries and developing countries have substantive and psychological factors which give rise to, and sustain, the theory of universal origin. Therefore this theory will not disappear. However, it is difficult to support it theoretically. ${ }^{34}$ Even in Europe the idea of human rights did not exist in pre-modern days. What existed were specific rights or privileges of persons belonging to specific groups or classes. For example, rights guaranteed in the Magna Carta were not rights of human persons per se. They were the special rights or privileges of specific persons such as peers, feudal lords, and the clergy. Rights characterized as those of indi-

\footnotetext{
${ }^{33}$ Professor TYAGI claims that it has been asserted that the history of human rights began with the Magna Carta; that the human rights movement was initiated by Western scholars or statesmen; that the civilized nations of the Western world fought two world wars for the reinstatement and protection of human rights; and the like. He argues that "all these assertions reflect a typical Western 'monopoly of wisdom'". Loc.cit.n.32 at 119. Similar arguments are made by many Third World intellectuals.

${ }^{34}$ ONUMA, loc.cit.n. 17 at $7-8,16$ n.52.
} 
viduals abstracted from specific belongings were born only after corps intermédiares were dissolved in the formation of sovereign states. ${ }^{35}$

Every civilization in the past had its own mechanisms to pursue the spiritual and material well-being of people. However, they were not characterized as human rights mechanisms. They protected the interests of people in various ways, although in a very limited manner when seen from today's perspective. With the spread of the sovereign states system and the capitalist economy, however, these mechanisms disappeared, at least on the surface. Instead, we have today human rights mechanisms not only in Europe but in other regions as well, although their effectiveness varies greatly from one society to another.

The mechanism of human rights has proved to be the most effective means for the protection of the vital interests of human persons in the modern period. However, as a human product it is not immune from flaws. It must be replaced or supplemented by some other useful mechanisms when it does not work well or when its flaws become apparent. Thus it is useful to search for the homeomorphic or existential functional equivalent of human rights ${ }^{36}$ in various civilizations so that we may adopt their merits. This does not mean asking whether human rights per se existed in non-Western civilizations. Such a question is theoretically futile. It is also undesirable for discussions on human rights to center on the dichotomy of 'universality vs relativity' as it creates further antagonism between developed and developing countries. Far more constructive and meaningful is it to seek common standards and frameworks of human rights which are based on today's political, economic and social realities, as well as diverse civilizational underpinnings. These standards and frameworks must be accepted as legitimate by as many people as possible, transcending national boundaries and civilizational backgrounds. The intercivilizational approach seeks such standards and frameworks.

\footnotetext{
"5uring this process the Aristotelian idea of a human person as a zoon politikoon was replaced by the idea of an abstract individual. The absorption of the decentralized powers of corps intermédiares by the absolutist state, the destruction of rural communities by the progress of capitalist economy, the decline of the authority of Christianity, and the rise of the theory on social contract and natural rights were needed to give birth to the idea of human rights (see the arguments and references in ONUMA, loc.cit.n.17 at 8-9, 16 ns.50 and 54). One could talk of forerunners or similar ideas of human rights in medieval Europe or antiquity, but not of human rights per se.

${ }^{36}$ R. PANIKKAR, 'Is the notion of human rights a Western concept?', 120 Diogenes (1982) 778. This article is one of the most important writings on the question of the universal or particular origin of human rights.
} 


\section{CRITICAL ANALYSIS OF THE EXISTING ASSESSMENT OF HUMAN RIGHTS PRACTICE}

\subsection{Analysis of the international assessment of human rights by major human rights NGOs}

When governments, international organizations and NGOs are engaged in improving human rights conditions, they should avoid selecting target states arbitrarily. This is important for the following reasons. First, international society has limited resources with which it can improve its human rights conditions. However, international actors have thus far tended to select target states either for political or for haphazard reasons, and have thereby often ignored more serious cases of violations. As to which human rights conditions should be focused, it is necessary to decide on the basis of priorities from the viewpoint of common human rights policies. Second, 'human rights' should not be an excuse for great powers to put pressure on smaller nations. There must be objective and intercivilizational standards for assessing human rights conditions which are valid to all nations. Third, such objective standards are needed in order to overcome resistance from targeted states, which often resort to a criticism of double standards or arbitrariness in human rights diplomacy by the developed countries and international organizations.

Thus far, many experts and some Western governments, international organizations, and human rights NGOs have published information and assessments of human rights conditions in various countries. Influential media institutions have played their part too. In particular, major human rights NGOs have played an important role by regularly providing vivid information on human rights violations. Through these publications people can learn of human rights violations on a global scale. Some of these violations are not reported by the ordinary media and only reach the public through those publications, which have also contributed to putting pressure on oppressive regimes. Further, one could compare and even rate human rights conditions on a country by country basis through some of those publications. These publications are widely] regarded as more reliable than government publications because of the independent status of the NGOs concerned and their devotion to the cause of human rights. The NGOs have fulfilled, are fulfilling, and will fulfill an important public function in disseminating crucial information on human rights violations all over the world, giving human rights education and training, providing food and fulfilling other basic needs for the poor and disadvantaged. Their role in monitoring, supplementing, and rectifying the human rights policies of governments and international organizations should be appreciated and encouraged. 
However, unlike activities of the governments and international organizations, ${ }^{37}$ their activities have not been fully scrutinized thus far. This is a serious problem, given their crucial importance and global influence. The objectivity and reliability of their activities must be critically analyzed and evaluated, and their legitimacy must be enhanced.

Let us first reflect on Amnesty International Report, probably the most well-known among the NGO human rights reports. The 1999 edition, ${ }^{38}$ which covers 142 countries, starts with an introduction and a few essays dealing with issues such as campaigns, human rights education, and work with international organizations. It then reports human rights conditions country by country, spending half a page to four pages on each country. The method employed is purely descriptive. The report states explicitly that Amnesty "does not grade countries according to their record on human rights". ${ }^{39}$ Rather, the purpose of Amnesty is "to prevent some of the gravest violations by governments of people's fundamental human rights", focusing on freeing "prisoners of conscience", ensuring fair and prompt trials, abolishing the death penalty, torture and other cruel treatment of prisoners, and ending extrajudicial executions and 'disappearances'. ${ }^{40}$ Thus, it almost exclusively deals with civil and political rights, and pays little attention to economic, social and cultural rights, although it "considers human rights to be indivisible and interdependent"." Little explanation is provided regarding the] method through which Amnesty selects countries, allocates pages and describes each country's human rights conditions. This criticism also holds for the grounds for its judgments which are included in the descriptions. It is difficult for readers to judge the standards and procedures applied in these critical areas. Given the huge influence which Amnesty and its annual report have on a global scale, this lack of transparency and accountability should be rectified.

Human Rights Watch World Report has similar characteristics. The 1996 edition $^{42}$ starts with an introduction, and surveys human rights conditions in some sixty-eight countries and areas, country by country and arranged according to regional groupings, including a brief overview of each region. The Re-

\footnotetext{
${ }^{37}$ The UN Human Rights Commission, its Sub-Commission, as well as committees and courts under human rights conventions have engaged in the assessment of human rights situations when they take up cases of human rights violations within their mandate or jurisdiction. The problems they face in their assessment activities are different in nature. The assessment of human rights situations by national governments has been criticized in various ways (See, e.g., the critical review of the US Department of State's Country Reports on Human Rights Practices by the Lawyers Committee for Human Rights, published annually since 1979).

Amnesty International Report 1999 (Amnesty International Publications, London, 1999).

39. Amnesty International Report 1996 (Amnesty International Publications, London, 1996), ii.

40 Ibid. The 1999 version employs the term "civil and political rights" instead of "fundamental human rights".

"Ibid.

${ }^{42}$ Human Rights Watch World Report 1999 (Human Rights Watch, New York etc., 1999).
} 
port ends with brief descriptions of specific issues and campaigns such as the academic freedom and child soldiers issues. Again the method is descriptive, with sporadic value judgments on the human rights conditions presented. Like Amnesty International Report, it deals almost exclusively with civil and political rights, showing little concern for economic, social and cultural rights. Nor does it satisfy the requirements for accountability and transparency in its descriptions and judgments.

Freedom in the World by Freedom House (1996 edition) ${ }^{43}$ is different from the former two Reports in the following respects. First, it evaluates political and civil rights in 191 nations and 57 related territories by grading them from 1 (most free) to 7 (least free), and classifies countries as 'free', 'partly free' and 'not free'. Secondly, it provides information on economic systems, purchasing power parities, life expectancy and, for most of the countries it covers, the population percentage by ethnic groups. Finally, it contains a table of social and economic comparisons, composed of real GDP per capita and life expectancy. ${ }^{44}$ These facts seem to suggest that Freedom House has more interest in economic, social and cultural rights than Amnesty and Human Rights Watch have. In fact, Freedom House published another annual report, World Survey of Economic Freedom 1995-1996, in 1997. ${ }^{45}$ It deals with six economic freedoms (to hold property, earn a living, operate a business, invest one's earnings, trade internationally and participate in the market economy), and rates 82 countries on a scale from zero to three.

However, the basic stance of Freedom House has far more serious problems than Amnesty and Human Rights Watch. First, Freedom House not only describes human rights conditions in countries all over the world, but also rates them. Its arbitrariness in rating countries with diverse civilizational backgrounds is most problematic. Second, the economic rights that Freedom House regards important are almost exclusively freedoms to undertake economic activities in a capitalist market economy. They are very different from the economic rights guaranteed in major international human rights instruments such as the ICESCR.

In order to rate countries by human rights standards one must have sophisticated methods which are endorsed from a number of perspectives. First, they must reflect major international human rights instruments including the Universal Declaration of 1948, the ICESCR and the ICCPR in a comprehensive and well-balanced manner. Otherwise they cannot have international legitimacy. Second, they must reflect major religions, cultures and societal norms in a comprehensive and well-balanced manner. Otherwise they cannot claim transnational and intercivilizational legitimacy, which is not necessarily represented

\footnotetext{
: Freedom House Survey Team, Freedom in the world: The annual survey of political rights \& civil liberties 1995-1996 (New York, 1996).

${ }^{4}$ Ibid. 530-538, and the first page of each country's review.

"R.MESSICK (ed.), World Survey of Economic Freedom 1995-1996 (New Brunswick, 1997).
} 
by 'international', i.e. intergovernmental, instruments on human rights. Third, they must satisfy basic requirements of statistical methodology ${ }^{40}$ Otherwise they cannot claim scientific legitimacy. Finally, they must make explicit the substantive bases and procedures which are employed to reach a rating, such as (1) substantive standards of selection and judgment of data; (2) actual data and materials used; (3) information as to who selected and operationalized them, and in what capacity; (4) the procedures adopted to minimize biases and preconceptions; and (5) other requirements for transparency and accountability.

When assessed against the above critical reuirements, the survey methodology in Freedom in the World is far from satisfactory. Although it presents checklists of civil and political rights, it does not elaborate by what specific standards and procedures it classifies countries from most free to least free. It claims that "Freedom House does not have a culture-bound view of democracy"47 $^{147}$ but does not substantiate that claim. In 1986, GOLDSTEIN criticized Freedom House, saying that "the basis of scores seems to be entirely impressionistic; furthermore, the scales are obscure, confusing, and inconsistent and change from year to year". ${ }^{48}$ Eight years later, basically the same criticism was expressed by GUPTA et al. Referring to Freedom in the World, they pointed out that "[n]o specific attempt is made to evaluate the respective weight of one freedom vis-à-vis the other. Rather, apparently intuitive overall judgment is made". ${ }^{49}$ Similar criticism applies to the World Survey of Economic Freedom 1995-1996.

Even in the case of factual observations without ratings, such as those by Amnesty International and Human Rights Watch, the requirements of objectivity, international legal foundation and intercivilizational legitimacy must be satisfied. One can hardly escape from one's own subjective judgments in collecting facts, selecting perspectives, weighing them, and in many other respects. The problem becomes even more serious if one rates various countries by judging the degree of freedom in these countries. The most effective ways to minimize subjectivity, preoccupation and arbitrariness in making observations and judgments are: (1) make explicit the bases, materials and procedures used in selecting, observing and assessing the human rights situations (to satisfy the requirement of transparency); (2) invite outside criticism on the methods used and conclusions drawn; and (3) improve both methods and conclusions by including constructive criticism (to satisfy the requirement of discursive legitimacy).

\footnotetext{
${ }^{46}$ See R.BARSH, 'Measuring human rights', 15 Human Rights Quarterly (1993) 87-121.

"Loc.cit.n.43 at 531.

4s R. GOLDSTEIN, 'The limitations of using quantitative data in studying human rights', in T.JABINE \& P.ClaUdE (eds.), Human rights and statistics (Philadelphia, 1986) 48.

49. GuPTA et al., 'Creating a composite index for assessing country performance in the field of human rights', 16 Human Rights Quarterly (1994) 137.
} 
However, none of the reports of the major human rights NGOs (not only the 1996 edition but other editions as well) meets these requirements. They do not set out the method, procedures and evidence of their observation and judgment in an explicit and elaborate manner. What they do provide are sources of information and the very general policies of the authors. It is almost impossible to judge the objectivity, precision, reliability, validity, legal foundations and intercivilizational legitimacy of the descriptions and assessments of these reports.

These NGOs started their activities in the realm of the protection of civil rights, and gradually expanded their activities. In this process, they have played an indispensable role in mitigating cruelties of human rights violations around the world for years. It should also be admitted that some sources of information must be kept secret to protect the informant from repressive governments or non-governmental violators of human rights. Thus, one may object, this author's criticism is too harsh. However, the predominant image of human rights held by a huge number of people is largely influenced by the activities of these NGOs, which are reported by world-wide media. Moreover, although to a certain extent based on misunderstandings or unfounded preconceptions, some people in developing countries are suspicious and critical of the activities of the NGOs concerned. Such suspicion and antagonism constitutes an obstacle to the dissemination and expansion of human rights to the people in the developing countries. Given these facts, the activities of the NGOs must be constantly scrutinized, their flaws must be rectified, and their intercivilizational legitimacy must be strengthened. Transparency and accountability are not only required of governments and international organizations, but also from influential non-governmental actors. Only by satisfying these requirements can they respond to the criticism of cultural imperialism or biased self-righteousness of the West, often made by Third World countries.

\subsection{The World Human Rights Guide and its problems}

Charles Humana's World Human Rights Guide has been far less influential than the reports of the major human rights NGOs. However, from a theoretical perspective it is more interesting because it explicitly elaborates the method of assessment. It covers states with a population exceeding one million, and assesses conditions of forty rights in these countries. Its main sources of information are major Western human rights NGOs and Western mass media. It classifies the degree of protection of rights into four categories: (1) unqualified respect, (2) qualified respect with occasional breaches, (3) frequent violations, and (4) constant pattern of violations. In the assessment, it weighs seven sorts of violations of freedoms involving physical suffering. In this way, it assesses human rights conditions in the countries with a rating from $100 \%$ to 
$0 \% .{ }^{50}$ HUMANA's index was adopted by the UNDP as a human freedom index in the Human Development Report 1991. ${ }^{51}$ However, this decision was severely criticized by developing countries, and the index was thus abandoned in the subsequent versions of the Report. ${ }^{52}$

Although a human development index should incorporate human rights perspectives, the decision to use HUMANA's index was wrong. His index shares a fundamental problem with the major reports described above: failure to embrace internationally recognized human rights in a comprehensive manner. The existing international human rights instruments such as the 1966 International Covenants on Human Rights and the 1993 Vienna Declaration formulate respect for and ensurance of human rights in a comprehensive and interdependent manner. However, HUMANA fails to reflect this formulation. He excessively focuses on civil and political rights, thereby underestimating the significance of economic, social and cultural rights.

HUMANA claims that he adopted "human rights which can be clearly assessed" as his criterion. ${ }^{53}$ However, he includes few economic, social and cultural rights: only three out of the forty rights come from the ICESCR. He justifies this selection by arguing that "the articles [of the ICESCR] usually refer to vague guarantees such as 'recognizing the right of' or 'taking steps towards' respecting a particular human right" ${ }^{54}$ By citing Article 12(2) of the ICESCR, he says that "[s]ince promises and aspirations cannot be measured, the questionnaire could make only limited use of the articles of the ICESCR".${ }^{55}$ However, this argument cannot be maintained.

Article 12(2) provides for the right to the enjoyment of the highest attainable standard of health. To achieve the full realization of this right it provides for such steps as the reduction of the stillbirth-rate and of infant mortality; the improvement of environmental and industrial hygiene; the prevention, treatment and control of epidemic and other diseases; and the creation of conditions assuring medical service and medical attention in the event of sickness. One can show the degree of the realization of 'promises' of the states parties to take these steps by objective indices such as the rates of stillbirth, infant mortality, epidemic mortality, the number of medical doctors, nurses and hospitals per unit population, and similar data. These figures can be used either as indices

\footnotetext{
5i) C. Humana, World Human Rights Guide, 3rd ed.(New York/Oxford, 1992) 3-6.

"Human Development Report 1991 (UNDP, New York/Oxford, 1991) 19-21.

5 Human Development Report 1993 (UNDP,New York/Oxford, 1993) 105. See also BARSH, loc.cit.n.46 at 87-90; M.Ul HAQ, Reflections on Human Development (New York/Oxford, 1995) 67-72.

${ }^{53}$ HUMANA, op.cit.n.50 at 3.

${ }^{34}$ Ibid. 7-8.

${ }^{55}$ Ibid. 8. In employing this argument, HUMANA ignored earlier studies such as GoLDSTEIN's, which had demonstrated that the area of economic and social rights has far more reliable and operationalizable data than the area of civil and political rights. Cf. GOLDSTEIN, loc.cit.n.48 at 40 et passim).
} 
indicating the improvement or degradation of the human rights condition in a certain country, or as indices of international comparison during a certain period.

This is true for other economic, social and cultural rights as well. For example, HUMANA does not address protection of and assistance to the family (Art. 10 of the ICESCR), the right to an adequate standard of living (Art. 11), nor the right to education (Art. 13). However, the enjoyment of these rights can be assessed more objectively than the rights which he examines. For example, the question of whether and how adequately a state accords to mothers paid leave or leave with adequate social security benefits can at least be assessed indirectly by inquiring into the existence of such institutions, and the amount and period of such payments or security benefits. The same can be said of data on daily caloric intake per person, the literacy rate, and the like. Although expressed in an aggregated manner, these figures can be useful in assessing the right to an adequate standard of living and the right to education.

It is true that there is room to argue whether and to what extent these figures can adequately be used to show the degree of enjoyment of the rights of individuals. Especially, if one requires sophisticated methods and results, it would be difficult to use the economic, social and cultural indices for the assessment of human rights. Most of the existing data are collected and provided by experts and institutions dealing with economics as well as development studies, without reference to human rights experts or institutions. They are expressed in aggregated forms, and therefore cannot be directly used in assessing the enjoyment of human rights by individuals. In utilizing the data, one must avoid 'quantitative fetishism', which is often seen in the case of experts on ecnomic or development theories and practices. ${ }^{56}$

\footnotetext{
5* As to problems and difficulties involved in using socio-economic data for measuring human rights, see GoLDSTEIN, loc.cit.n.48 at 38-54; the Report of the Seminar on appropriate indicators to measure achievements in the progressive realization of economic, social and cultural rights (Geneva, 25-29 January 1993), A/CONF.157/PC/73 (20 April 1993) 9 et passim, esp. 12, 17, 28-30; BARSH, loc.cit.n.46 passim; A.CHAPMAN, "A "violations approach" for monitoring the International Covenant on Economic, Social and Cultural Rights',18 Human Rights Quarterly (1996) 29-36, esp.33-36. After pointing out the difficulties in using socio-economic statistical data for measuring economic, social and cultural rights, CHAPMAN proposes a "violation approach" as a more feasible method to be adopted by the UN Committee on Economic, Social and Cultural Rights (ibid. 36-66). Although his efforts should be appreciated, further efforts must be made to search a way of using statistical data for the assessment of the progressive realization of socio-economic rights in a positive, rather than a negative, manner. We should start with a modest assessment based on the combination of qualitative and quantitative methods, avoiding quantitative fetishism, and continue making efforts to improve the method.
} 
The problem of how to objectively assess human rights conditions is not limited to economic, social and cultural rights. It is even worse with civil and political rights. ${ }^{57}$ Yet, the existing literature has engaged in assessing the conditions of civil and political rights. HUMANA's method is seriously flawed in this respect. He assesses human rights conditions by four grades, from unqualified respect to constant violation, with triple weight ascribed to seven items, the violation of which involves physical suffering. However, he fails to provide specific criteria for the assessment of the human rights conditions according to these scales. Without such concrete criteria, arbitrary judgment is unavoidable. ${ }^{58}$ HUMANA's selection of rights with extra weight reveals this arbitrariness. He simply relies on what he "regards as a straightforward exercise of common sense" ${ }^{159}$ in selecting prioritized rights. There might be global agreement on giving extra weight to the rights whose violation involves physical suffering. However, it is highly doubtful whether the entire international community would agree to the seven items which HUMANA actually lists. ${ }^{60}$

Problematic features of HUMANA's Guide are evident. Although it claims to assess 'human rights', it almost exclusively deals with civil and political rights. Its assessment is based on the subjective view of HUMANA himself, and

The most important thing at present is to have a more balanced and the most comprehensive picture of the assessment of human rights which is attainable and which reflects the existing international instruments on human rights. It would be ridiculous to tolerate crude methods in assessing civil and political rights, and to require highly sophisticated methods in assessing economic, social and cultural rights. Rectification of the existing assessments which are based on even less sophisticated methods but ignore the abundance of useful socio-economic data, should be a priority. If the Committee takes a "violation approach", this may invite a confrontational atmosphere even in the field of economic, social and cultural rights. One should remember that the purpose of assessment is not the assessment per se, but to encourage states parties to achieve a better realization of economic, social and cultural rights.

"GoLDSTEIN, loc.cit.n.48 at 40, 41, 43, 44.

$\$ \$$ For criticism of HUMANA's arbitrariness, see also BARSH, loc.cit.n.46 at 104-5; GUPTA et al., loc. cit.n.49 at 138-40, esp. 140 .

59 HUMANA, op.cit.n.50 at 6.

This is particularly the case with the "freedom from capital punishment". The Second Optional Protocol to the ICCPR, aiming at the abolition of the death penalty, is adhered to by only 33 out of around 190 states in the present international society (as of 1 October 1998). The prohibition of the death penalty does not constitute a contemporary norm of general international law. Furthermore, from an inter-civilizational perspective the question how to judge the death penalty is a fundamental one involving one's world view and one's religious, philosophical and ontological beliefs, on which debates will continue for years to come. Whatever HUMANA's personal view may be, the "freedom from capital punishment" cannot be an objective, even less a weighted, criterion to assess contemporary human rights conditions all over the world. 
Western NGOs and media institutions. ${ }^{61}$ The Westcentric narrowness is evident in the very definition of human rights. HUMANA asks "[H]uman rights--what are they?' and answers: ' $[\mathrm{H}]$ uman rights are the laws, customs, and practices that have evolved over the centuries to protect ordinary people, minorities, groups, and races from oppressive rulers and governments' (emphasis added). ${ }^{62}$ It is true that human rights were established to protect human persons mainly from oppressive rulers and governments. Today, they are still the major violators of human rights. Yet, the human rights now globally recognized are not limited to rights characterized as protection from rulers and governments. They are the totality of economic, social, cultural, civil and political rights, which should be characterized as vital means of realizing human dignity. HUMANA lacks this contemporary international and inter-civilizational perspective, but the flaw is not limited to his work. Although not so apparent, failure to reflect the comprehensive notion of human rights embodied in the current international human rights instruments is common to the annual reports of the major human rights NGOs described above. Lack of concrete criteria for the description and assessment of human rights conditions is also common to all. None have provided sophisticated methods for the assessment of human rights conditions, which should be tested in an empirical and objective manner.

\section{CONDITIONS OF INTERCIVILIZATIONAL STANDARDS AND FRAMEWORKS OF HUMAN RIGHTS}

\subsection{Liberation from Westcentrism}

The foregoing analyses reveal the prominence of the Westcentric way of thinking in the contemporary discourse and standards of human rights. Human rights have been claimed, argued, studied, and realized in Western societies for the last two centuries. Compared with this long history, non-Western societies have been late in dealing with human rights. Moreover, not only human rights but most contemporary issues are framed, defined, and influenced by Western intellectuals and media institutions. It is thus natural that the discourse on human rights has been influenced by Westcentric approaches and perspectives.

\footnotetext{
${ }^{6}$ HUMANA lists major human rights NGOs and mass media institutions as sources of information. This in itself should be appreciated from the perspective of transparency and accountability of the assessment. However, the institutions included in the list are almost exclusively US, British and French (op.cit.n.50 at xx). Although some of them may claim an international character, no one can deny that they are lead and financed by Western activists, capital and supporters. NGOs and media institutions in developing countries, whose population accounts for more than $80 \%$ of the world's total, and even those in developed countries other than the US, the UK and France are ignored. Lack of international and inter-civilizational legitimacy is evident. Although to a varying degree, this flaw is more or less common to other publications.

C. Humana, op.cit.n.50 at 4.
} 
Non-Western intellectuals and leaders have also been responsible for the prominence of Westcentric discourse. Although many of them have criticized Western human rights discourse or diplomacy, their purpose is often the rebuttal of external criticism of human rights conditions in their own countries, and in doing so they have often resorted to the principle of non-intervention or domestic jurisdiction. Although understandable from the perspective of their humiliated past as the target of imperialistic interventions, it reveals their political motivation as well. Such politically motivated criticism reinforces, rather than diminishes, the strength of the Western claims. Moreover, despite their criticism of the West's preoccupation and biases, they themselves unconsciously share Westcentric ways of thinking because of their educational backgrounds, their tacit longing for the West, and their Westernized way of life.

When one discusses human rights within the framework of universality versus relativity or particularity, one almost always takes up an 'Asian way', 'Islam', the 'ethics of Confucianism', and the like as specific examples of particularity. One seldom refers to the 'European way' or 'Christianity'. as an example of particularity. It is almost always assumed that what is universal is something Western, while particularity refers to something non-Western. This is strange given the simple fact that an overwhelming majority of the world's population is non-Western. This assumption is not limited to Westerners. When non-Western intellectuals criticize human rights diplomacy as Western universalism, defending their cultures under the name of relativism or particularism, their argument shares, and even reinforces the assumption, albeit tacitly and unconsciously. As long as one relies on this assumption, there is little room left to think that something non-Western, whether it be Asian, African, Islamic or Confucian, can be universally valid.

Arguments made by LEE KWAN YEW and others share these problematic features. They are often politically motivated, and unconsciously share the Westcentric dichotomy of 'universality vs particularity'. Yet, the emergence of East Asia as the probable center of the global economy in the twenty-first century, and accompanying controversies over 'Asian ways' or 'Asian human rights' have brought about some positive change. They have made many people realize that more inter-civilizational dialogue is needed, if ever human rights are to be actually globalized. The awareness of the fundamental conflicts underlying controversies over human rights, as described earlier, ${ }^{6,3}$ supports this view.

Today, a large number of ideas and institutions originating in Europe are shared or used by peoples all over the world: the Christian calendar, the meridian, the metric system, the English language, the sovereign states system, and others. However, this does not mean that they are inherently universal. Rather they have become globally shared as a result of the worldwide colonial

\footnotetext{
See supra, section 2.
} 
rule and hegemony by European powers up to the middle of the twentieth century, and the economic, military, cultural and informational hegemony of the US during the postwar period. Needless to say, not all European ideas and institutions were forced on non-Europeans. Many of them, such as modern science, technology, medicine and industry, as well as the idea of democracy were voluntarily accepted by non-Europeans. The globalization of modern European ideas and institutions took place as a result of the mixture of voluntary acceptance and enforcement by external powers. ${ }^{64}$ The idea and institution of human rights is one of those Western ideas and institutions.

When ideas or institutions are expanded from their place of origin to other regions, their original nature or characteristic features are inevitably transformed in order to be accepted by the inhabitants of the regions to which they have spread. Characteristics of Christianity changed in the process of its universalization. It originated in Palestine, and spread over Europe, Africa, Latin America and other regions. In this process, in order to be accepted by 'pagan' Europeans and others, it changed the original features it possessed when it originated in Palestine. This was also the case with Islam, Buddhism, Confucianism, Marxism and other major belief systems. Human rights are no exception. They originated in Europe for protecting individuals from the abuse of the power of states. However, they have changed themselves and have become more comprehensive, including economic, social and cultural rights as well as collective rights. They have come to protect humans not only from the power of states, but from non-state actors as well (horizontal effect or Drittwirkung of human rights).$^{65}$ Assuming that what is universal is always Western would deny the inevitable transformation which any idea or institution undergoes in the process of its universalization.

From the perspective of purists or rigorists, such transformation is often regarded as a regrettable degradation or apostasy. Certain theorists could not tolerate the incorporation of economic, social and cultural rights, or the right of national self-determination into the category of human rights. There have certainly been problems with regard to the expansion of human rights, relating to both 'inflation' and the 'quality' of the notion of human rights. ${ }^{66}$ However, the very fact that large numbers of people in the Third World with diverse cultural or religious backgrounds have sought to formulate their claims or desires in terms of human rights demonstrates how attractive the formulation of human

\footnotetext{
See an interesting discussion between EISENSTADT and COOMARASWAMY in S.EISENSTADT, 'Human rights in comparative civilizational perspective', in A.EIDE and B.HAGTVET (eds.), Human rights in perspective (Oxford, 1992) 93-112.

${ }^{6}$ Moreover, some experts and many developing countries have argued for the 'third generation rights' such as the right to development. In 1986, the UNGA adopted the Declaration on the Right to Development.

See the concern with respect to "the haphazard, almost anarchic manner in which the expansion of human rights is being achieved", in P.ALSTON, 'Conjuring up new human rights', 78 AJIL (1984) 607.
} 
rights is. Therefore, the incorporation of various human rights other than the original civil and political rights in the process of universalization should be viewed as a victory, rather than a degradation, of human rights.

On the other hand, while enjoying various fruits of modern civilization, today's world seriously suffers from a variety of social diseases: social ethics which cannot control the 'progress' of modern weaponry; the hegemonic US that suffers from numerous murders, rapes, narcotic offenses and the breakdown of the family; the prosperous Japan that cannot cure diseases of social alienation symbolized by ijime (school bullying); the 'humanitarian' Western European nations with their cases of serious attacks on, and discrimination against, foreign labourers and Muslims; and the energy-consuming life-style of 'developed' nations which, if maintained and followed by developing nations, would bring with it the ruining of the human species through the deterioration of the global environment.

From this perspective, the merits and demerits of modern civilization which are associated with the European expansion all over the world should be seriously questioned. Human rights, being a product of this civilization, cannot be an exception. Their achievements as well as flaws, especially the merits and demerits of the individualistic and legalistic approach, must be scrutinized. The mechanism of human rights is an essential tool for realizing the well-being of humanity under the modern system of sovereign states and capitalist economy. It should be adopted by all nations, irrespective of their civilizational backgrounds. Precisely because of this global significance, Westcentric biases of human rights must be overcome, and their raison d'être must be grounded in an intercivilizational perspective.

\subsection{Liberation from liberty-centrism}

One of the most serious flaws in the human rights discourse is the equation of civil and political rights with human rights in general. This is not limited to a view that 'real' or 'authentic' human rights are civil and political rights. "The greatest part of the human rights discourse has been founded on this implicit equation. Economic, social and cultural rights have been referred to only in passing, or as a supplement. This way of thinking can be referred to as civil and political rights-centrism, or liberty-centrism. In fact, because of the prominence of the liberal paradigm in human rights discourse, human rights have

\footnotetext{
M.CRAnSTON, What are human rights (New York, 1964); M.BossuYT, 'La distinction juridique entre les droits civils et politiques et les droits economiques, sociaux et culturels', 8 Revue des droits de l'homme (1975) 783-820; E.VIERDAG, 'The legal nature of the rights granted by the International Covenant on Economic, Social and Cultural Rights', 9 Netherlands Yearbook of International Law (1978) 69-105. See also R.NOZICK, Anarchy, state, and utopia (New York, 1974) 167-74.
} 
often been equated with civil rights, rather than civil and political rights. The often adopted terminology 'human rights and democracy' demonstrates this tendency. In this expression, human rights represents civil rights, while political rights are expressed by 'democracy' rather than human rights. ${ }^{68}$ This tendency is especially strong in the US, which has been reluctant to accept economic, social and cultural rights as human rights. ${ }^{69}$

In Western societies, the spread and incorporation of human rights in positive laws went hand in hand with the secularization and liberalization of society. ${ }^{70}$ In this process, freedom from the arbitrary power of the state was regarded as most important. Violations of human rights by non-state actors such as private firms or terrorist groups were at first not considered part of the ordinary discourse on human rights. Even when they were considered as an issue of human rights, they were regarded at most as secondary problems. They were characterized merely as a question of the indirect or third party applicability (Drittwirkung) of the constitutional guarantee of human rights. Distrust in the central government and optimism in the private sector has been particularly strong in the US.

According to the classical theory, formulated against this historical background, human rights are classified into two groups: civil and political rights, which are freedoms 'from' the state, and economic, social and cultural rights, which are rights 'to' the state. Whereas the former requires states merely to restrain from the arbitrary use of power, the latter requires them to take positive measures. Thus, while the former can be called legal rights, it is difficult to characterize the latter as rights sensu stricto. Rather, they are political programs. This view ${ }^{71}$ has been predominant both in the domestic and international discourse on human rights. An overwhelming number of publications on human rights have, either explicitly or implicitly, shared this view. The dichotomy is still strongly maintained among many experts and an even larger number of non-experts.

At the same time, even after the adoption of the major declarations on human rights such as the US Declaration of Independence and the French Declaration of the Rights of Man and of Citizens, the Western powers treated human rights in an extremely uneven manner. During the period from the eighteenth

\footnotetext{
See an interesting observation by J.HABERMAS, 'Human rights and popular sovereignty', 7 Ratio Juris (1994) 1-13.

${ }^{6}$ For a critical analysis, see P.ALSTON, 'US ratification of the Covenant on Economic, Social and Cultural Rights', 84 AJIL (1990) 365-93. Some US experts as well as many non-US experts on human rights share this critical perspective.

${ }^{70}$ It is true that some developed societies are witnessing the resurgence of religion. This is mainly due to the fact that many people in modernized societies cannot play a role as expected in according to the image of 'autonomous individuals' independent from families, communities or other collectivities. They want something on which they can be dependent. Thus, the resurgence of religion in developed societies reveals problematic features of modern individualcentrism, which will be discussed later.

"See references in n.67.
} 
through the early twentieth century, in which they introduced human rights provisions in their constitutions, they simultaneously exploited wealth, domestically from villages and the working classes and internationally from the peoples in their colonies or from 'uncivilized' nations. Neither Western governments nor Western people in those days regarded the question of human rights as a top priority issue. Only when they became rich enough did they begin to regard human rights as an important issue, gradually making political slogans out of them. When blacks were lynched in the Southern US, and the British labour classes were suffering from the desperate working conditions described by ENGELS, there was neither Amnesty International nor Human Rights Watch to criticize these human rights violations.

However, the emergence of ex-colonies in international society and the post-war developments in human rights theory and practice mainly in Western (particularly Northern) European countries brought about, and are still bringing about, certain changes both domestically and internationally. First, the primacy of civil and political rights has been challenged by many developing countries and an increasing number of experts both in developed and developing countries. Until the first half of the twentieth century, most non-Western nations were either under colonial rule, or suffered from unequal treaties concluded with - actually, imposed by - Western powers and Japan. When they became independent, or liberated themselves from the unequal treaties, the first thing they had to do was to liberate their nations from poverty - the same as the Western powers and Japan had done in the early stage of their modernization. As was the case with the Western powers and Japan, it is difficult for the governments and the peoples at this stage of their development to regard civil and political rights as a matter of first priority. If they are interested in human rights, it is economic rights, especially the right to subsistence, ${ }^{72}$ that have a direct bearing on the day-to-day life of people. Many governments and intellectuals in developing countries have sought to formulate the right to development and to establish it as an internationally recognized right. Although many experts and human rights advocates are critical of a 'development first' thesis, an increasing number of experts are coming to understand the significance of economic rights for the poor, and becoming critical of excessive emphasis on civil and political rights. ${ }^{73}$

\footnotetext{
' See, e.g., the claim by the Chinese government in 'Human rights in China', 34 Beijing Review (November 4-10, 1991) 9.

3 H. SHUE, Basic rights (Princeton, N.J.,1980) is an epoch-making study. See also R.VINCENT, Human rights and international relations (Cambridge, 1986); U.BAXI (ed.), The right to be human (New Delhi, 1987); P.MEYER-BISCH, Le corps des droits de l'homme (Fribourg, 1992); C.MuZAFFAR, Human rights and the New World Order (Penang, 1993) and studies dealing with economic, social and cultural rights, most of which are critical of libertycentrism.
} 
Second, recent studies by experts and practices of monitoring bodies under human rights conventions have demonstrated the relative differences between, and interdependence of, civil and political rights, and economic, social and cultural rights in various ways. ${ }^{74}$ For states to effectively guarantee civil and political rights, a sufficient infrastructure in terms of organizations, financial resources, ethos of public devotion, as well as education and training of human resources are needed. It is only after this infrastructure is established that one can reasonably expect the protection of civil and political rights by mere restraint of state powers. For example, the realization of freedom from arbitrary arrest, torture and inhuman treatment requires states to take positive action such as giving human rights education and training to policemen, jail officers, military officers and soldiers, as well as cultivating competent lawyers. Merely restraining from the arbitrary use of power by the state is not enough. ${ }^{75}$ The Human Rights Committee has requested the states parties to the ICCPR not only to refrain from the abuse of state power, but also to take positive measures, including affirmative action programs, to fulfill the obligation to ensure all individuals within their territory and under their jurisdiction the rights recognized in the Covenant. For example, in its General Comment No. 6 (16), the Committee said that "[t]he expression 'inherent right to life' cannot properly be understood in a restrictive manner, and the protection of this right requires that States adopt positive measures". " Similar comments have been made with regard to the prohibition of torture and cruel, inhuman or degrading treatment or punishment, and other freedoms. ${ }^{77}$

Other monitoring bodies under various human rights conventions have shown attitudes similar to that of the Human Rights Committee. For example, the European Court of Human Rights has made it clear that civil and political rights cannot be protected merely by self-restraint of state power and that their effective protection requires positive measures by the government. In its judgment in the Marckx case (1979), the Court reaffirmed its earlier position that the object of Article 8 of the European Convention for the Protection of Human Rights, which provides for the right to respect for [a person's] family life, is 'essentially' to protect the individual against arbitrary interference by the public authorities. However, it added that "[i]l ne se contente pourtant pas d'astreindre

\footnotetext{
"4 G.VAN HOOF, 'The legal nature of economic, social and cultural rights', in P.ALSTON and K.TOMASEVSKI (eds.), The right to food (Dordrecht, 1985) 97-110; M.CRAVEN, The International Covenant on Economic, Social and Cultural Rights (Oxford, 1995) 9-16; SHIN H., Jinken jouyaku jo no kokka no gimu [Obligations of states under Human Rights Conventions] (Ph.D.dissertation, University of Tokyo, Faculty of Law, 1995) 11-69 et passim; M.SCHEININ, 'Economic and social rights as legal rights', in A.EIDE et al. (eds.), Economic, Social and Cultural Rights (Dordrecht, 1995) 41-62.

${ }_{75}^{75}$ For a detailed study, see SHIN, op.cit.n.74 at 29-30, 173-81, 182-83.

General Comment No.6 (16) para.5 (CCPR/C/21/Rev.1, 5).

General Comment No.7 (16) para.1 (CCPR/C/21/Rev.1, 6). See also General Comment No. 20 (44) para.1 (CCPR/C/21/Rev.1/Add.3). See, further, SHIN, op.cit.n.74 at 71-80, 161200, 204-8, 237-65.
} 
l'Etat à s'abstenir de pareilles ingérences: à cet engagement plutôt négatif peuvent s'ajouter des obligations positives inhérentes à un respect effectif de la vie familiale" ${ }^{78}$ A similar view has been repeatedly reaffirmed by subsequent judgments such as those in the Airey case of $1979^{79}$ and in the case of Johnston and Others of $1986 .{ }^{80}$

Third, recent constitutional practices and theories in many developed countries have demonstrated the increasing importance accorded to economic, social and cultural rights. These rights were once characterized as merely political programs or abstract rights, lacking in judicial enforceability. The classic views of CRANSTON, BOSSUYT and VIERDAG, all elaborated before and in the 1970s, reflected this state of the law. However, in order to respond to the criticism that civil and political rights exist merely on paper for those without sufficient means of living, most developed countries have taken positive measures such as land reforms, social policies, protection of labor unions and progressive income taxes, thereby realizing economic and social rights. With the development of social welfare programs during the post-war period, constitutional theories and practices have gradually accorded a certain degree of judicial enforceability to certain economic and social rights. For example, the right to an adequate standard of living requires freedom from state violation of the subsistence of the individual before a guaranteed right to positive state measures. At least to the extent of the obligation of state abstention the right can be judicially enforced. ${ }^{81}$ Similar arguments have been raised for many other economic, social and cultural rights. ${ }^{\$ 2}$

This development can be seen at an international level as well. Monitoring bodies under the ICESCR, the European Social Charter, the American Convention on Human Rights and other human rights conventions, as well as the ILO have demonstrated that most economic, social and cultural rights have the above two aspects. ${ }^{83}$ In particular, the 1986 Limburg Principles on the Imple-

European Court of Human Rights, Marcks case, judgment of 13 June 1979, Ser.A No.31(1979) para.31.

Id., Airey case, judgment of 9 Oct.1979, Ser.A No.32(1979) paras.24-26.

* Id., case of Johnston \& Others, judgment of 18 December 1986, Ser.A No.112 (1986) para.74.

: A.EIDE, 'Economic, social and cultural rights as human rights', in EIDE et al. (eds.), op.cit.n.74 at 73, 37; id., 'The right to an adequate standard of living including the right to food', in ibid. at 101-2. This view is gradually becoming shared by an increasing number of international and constitutional lawyers in many countries. Practices of domestic courts as well as international monitoring bodies of human rights show a similar tendency.

SHIN, op.cit.n.74 at 38-45.

${ }^{83}$ J.DHOMMEAUX, 'La contribution du comité des droits economiques, sociaux et culturels des nations unies à la protection des droits economiques, sociaux et culturels', 40 Annuaire français de droit international (1994) 637-38; SHIN, op.cit.n.74 at 17, 38-45, 88-89, 343-98; SCHEININ, loc.cit.n.74 at 53-62; M.CRAVEN, The International Covenant on Economic, Social and Cultural Rights (Oxford, 1995) 28-29, 110-13, 181 et passim. 
mentation of the ICESCR, which provides in its paragraph 25 that "[s]tate parties are obliged, regardless of level of economic development, to ensure respect for minimum subsistence rights for all" ${ }^{84}$ has had a great influence on the theory and practice on economic, social and cultural rights. Today, one can no longer say: whereas civil and political rights are judicially enforceable, economic, social and cultural rights are not. Such categorical classification is too simplistic to describe the present status of enforceability of human rights.

Fourth, it is now widely recognized that violations by non-state actors such as terrorist groups, anti-governmental military groups and private companies are no less serious than those by state organs ${ }^{85}$ Another serious problem which is now characterized as an important issue of human rights is the collective or structural deprivation of human dignity by means of the patron-clientele relationship in rural communities, discriminatory social customs and other similar social institutions and practices. Seen from these perspectives, it does not matter whether human rights are violated by state organs or by non-state actors. What is important is the obligation of states to ensure that all human persons under their jurisdiction can enjoy subsistence with human dignity. The Human Rights Committee has repeatedly demonstrated that states parties must take positive measures so that human rights can be protected not only against the power of the government, but also against the power of non-state actors. ${ }^{86}$ The European Court, which had already tended to show this view in its judgments such as in the Marckx and Airey cases as described earlier, ${ }^{87}$ clearly recognized in its judgment in the Young, James and Webster case of 1981 that states must take positive measures to protect human rights in the private sphere. ${ }^{88}$

Fifth, doubt has been raised as to whether judicial enforcement is the most effective way to realize human rights. According to the predominant view, the judiciary is the final guarantor of human rights. Thus, whether a right in question is judicially enforceable should be the criterion for rights. However, whether the judiciary is actually the most effective organ to protect human rights depends on various conditions: whether the independence of the judiciary is guaranteed in law and in fact; whether the prevailing culture of a society allows ordinary people to appeal to a court for vindicating their rights; whether a member of a society can reasonably expect to retain a lawyer. Evidently, many of these conditions do not exist in most of the developing countries, which constitute $80 \%$ of the world population. Like many other 'general' or 'universal'

\footnotetext{
E/CN.4/1987/17 (8 Jan.1987) 3.

Major human rights NGOs once dealt only with violations of human rights by state authorities, and were reluctant to tackle those perpetrated by non-state actors. Gradually they have come to recognize that the latter are as serious as the former. Today, the activities of several NGOs cover human rights violations by non-state actors as well.

See SHIN, op.cit. n.74 at 161 et passim.

Loc.cit.Nos.78-79.

In the case of Young, James and Webster, judgment of 13 Aug.1981, Ser.A No.44 (1981) para. 49.
} 
ideas, theories and propositions, the idea of the judiciary as the final guarantor of human rights presupposes the conditions which exist in Western societies. When tested against non-Western societies, its validity becomes highly questionable.

It is certainly true that in some cases and/or societies, judicial enforcement can be most effective. However, there are also many cases and/or societies in which a government social policy, human rights education and publicity, supervision by domestic as well as international media and monitoring bodies, or the combination of these factors can be more effective. EIDE argues that the theoretical legalist debate on whether economic and social rights are justiciable largely misses the point because what is significant is the effective protection of the rights in question, be it through courts or through other mechanisms. ${ }^{89}$ This perspective is of critical importance whenever we deal with human rights, not only in developed societies but in any society at this globe. ${ }^{9}$ This perspective enables us to free ourselves from placing excessive expectations on the judiciary, and promotes more balanced discussions on the multi-faceted mechanism of realizing human rights, including the role of national governments, domestic and international human rights committees, NGOs and the media institutions.

Finally, the interdependence and indivisibility of human rights has been repeatedly reaffirmed in international human rights instruments. Until the 1970s this notion was mainly advanced by socialist and developing countries which emphasized economic and social rights or, more correctly, economic development of the nation, against the predominant civil and political rights-centrism of the Western, developed, countries. The Proclamation of Teheran of 1968 declared that "[s]ince human rights ... are indivisible, the full realization of civil and political rights without the enjoyment of economic, social and cultural rights is impossible. The achievement of lasting progress in the implementation of human rights is dependent upon sound and effective national and international policies of economic and social development". ${ }^{11}$ The 1977 UN General Assembly Resolution "Alternative Approaches and Ways and Means within the United Nations System for Improving the Effective Enjoyment of Human Rights and Fundamental Freedoms" provided that "[t]he realization of the new international economic order is an essential element for the effective promotion of

\footnotetext{
$\because$ A.EIDE, 'Future protection of economic and social rights in Europe', A.BLOED et al.(eds.), Monitoring Human Rights in Europe (Dordrecht, 1993). 214. See also P.MYER-BISCH, op.cit.n.73, at 165-166, 170; HIGGINS, op.cit.n.22 at 100-102 and SHIN,op.cit.n.74 at 10-15.

${ }^{\text {:i) }}$ It is true that in quite a few non-Western societies the judiciary plays an important role for the protection of human rights. India is one example. Indian judicial activism, especially its famous social action litigation, is based on modification of the predominant (=Western) theory of subjects of rights, the requirements of standing, justiciability and the like. This modification has been pursued from a perspective of the most effective way of protecting human rights in general, and thus can ease the rigid requirements on standing, etc.

The Proclamation of Teheran of 13 May 1968 para.13, in Human Rights: A Compilation of International Instruments (UN, New York, 1988) 45; also in 63 AJIL (1969) 674.
} 
human rights and fundamental freedoms and should be accorded priority"..$^{92}$ In these contexts, indivisibility and interdependence of human rights played an ideological role justifying the evasion of the effective protection of civil and political rights by socialist and developing countries.

Since the 1980s, however, the same notion came to mean literally the interdependence of human rights. In 1981, SEN argued that states must protect civil rights such as freedom of expression in order to realize the right to subsistence which developing countries regarded as most important. He demonstrated that the effective protection of freedom of the press and the free flow of information is of critical importance to prevent massive famines by citing examples in India, China and other countries. ${ }^{93}$ A number of experts and NGOs in developed countries have made similar arguments. For example, in 1992 Human Rights Watch, quoting the Chinese government's claim that the right to subsistence was most important, ${ }^{9 / 4}$ made an argument based on SEN's research. ${ }^{95}$ In this way, the interdependence of human rights has been claimed not only by governments and experts in developing countries but also by those in developed countries.

In 1993, the Vienna Declaration and Programme of Action provided that "[a]ll human rights are universal, indivisible and interdependent and interrelated. The international community must treat human rights globally in a fair and equal manner, on the same footing, and with the same emphasis". This formulation, which exemplifies the comprehensive notion of human rights, is of critical importance in that it is based on a consensus among nations with diverse civilizational, i.e. political, economic, social, religious and cultural, backgrounds. Naturally, in what sense we could talk of the indivisibility of human rights is a difficult question to answer. Given the limited resources on earth and the inevitable conflicts between human rights themselves, we cannot escape from prioritizing rights. However, there exists a widely shared consensus in the international community to the effect that one should avoid a one-sided emphasis on either civil or economic rights, and instead seek to realize the totality of rights in a balanced manner, paying due attention to the mutually supporting function of both categories of rights.

Together with these developments, classifications which seek to replace the traditional dichotomy between civil and political rights on one hand, and economic, social and cultural rights on the other, have been proposed by a number of experts. For example, according to VAN HOOF and EIDE, obligations of states can be classified into four groups: obligations to respect, to protect, to

\footnotetext{
A/RES/32/120 (16 Dec.1977), UNGAOR 32th Sess., Suppl.No.45 (A/32/45) 151.

A.SEN, Poverty and famines (New York,1981); A.SEN and J.DREZE (eds.), Famine prevention (Oxford, 1990).

${ }^{84}$ Information Office of the State Council, 'Human Rights in China', 34 Beijing Review (1991)

No.44:9.

"s. Indivisible Human Rights (Human Rights Watch, New York, 1992).

Vienna Declaration and Programme of Action, 25 June 1993, para.5 (A/CONF.157/23)
} 
ensure, and to promote. ${ }^{97}$ This classification enables a more elaborate analysis of human rights with regard to the relations between their objectives and their realization. Accordingly, it has been adhered to by an increasing number of experts. ${ }^{9}$ In this way, the relative, rather than absolute, difference between civil and political rights on one hand, and economic and social rights on the other, has gradually become recognized in recent years. The classification which categorically distinguishes the two groups of human rights is a historical one corresponding to an early stage of development in Western nations. It is not a universal and suprahistorical classification applicable everywhere and at all times. This view is steadily spreading among experts on human rights. ${ }^{99}$ One of the most important tasks today is to disseminate this comprehensive notion of human rights, and to strengthen the various means for their effective realization which are suitable for the people and the society in which the rights in question are to be realized.

\subsection{Liberation from individual-centrism}

In the theory and practice of human rights, the term 'human' has been assumed, imaged and understood according to the modern Western notion of the human being or human person. Other notions and images have, consciously or unconsciously, been excluded. As described earlier, this notion of a human is implicitly based on the image of a white, male and bourgeois Christian. Together with this qualification, the notion of a human has been equated with that of an individual. This equation is in fact a novelty, even in Western civilization. For a long time in pre-modern Europe, a human being was a member of a family, a village, a church, a guild or another group. It was difficult for premodern Europeans to think of an 'autonomous individual' independent from these social institutions. A human came to be characterized as an individual only when the sovereign state and market economy had dissolved various corps intermédiaires. Humans, both constrained and protected by these groups, now came to be dissociated from them and confronted the newly born Leviathan (the sovereign state) and market economy as naked individuals. The process which produced these individuals involved various forms of violence. Absolutist states fought against intermediate powers. Capitalist economy destroyed the tradi-

\footnotetext{
VAN HOOF, loc.cit.n.74 at 106-8. This classification is basically based on A.EIDE, 'Study on the right to adequate food as a human right'(E/CN.4/Sub.2/1983/25).

\$S See CRAVEN, op.cit.n.74 at 109-14; SHIN, op.cit.n.74 at 32-45.

"See J.DONNELLY, 'Post-cold war reflections on the study of international human rights', 8 Journal of Ethics and International Affairs (1994) 104-10; SHIN, op.cit.n.74 at 3 et passim; ASHIBE, op.cit.n.22 at 83-4.
} 
tional autonomous village economy. Religious powers fought against each other, as well as against secular powers. ${ }^{1(0)}$

The modernity based upon the 'autonomous individuals', established after such sacrifices, brought forth various benefits to a large number of people: liberation from religious powers, from institutions based on social standings, and from feudalistic rule of villages or guilds, and liberation of women from stringent social institutions and family constraints. On the other hand, people came to have a strong sense of belonging to a nation state, which gradually dissolved these intermediate bodies. A modern person ceased to die for his/her clan, religious or feudalistic community, but came to die willingly for his/her nation state. For most cases, an 'individual' has never existed as an abstract individual. He or she has existed, and still exists, as an individual member of a nation state.

Thus, the liberation of a human from his/her intermediate body is at the same time absorption of a human into a nation state. The establishment of the 'individual' means a transformation from a world where people identified themselves as Christians, as bourguignons and were recognized as such, to a world where people identify themselves as French and are recognized as such. A modern person can enjoy his/her life in a meaningful manner and can fully realize his/her potentiality as a member of a nation state. This is evident if one sees how modernity has alienated those who have legally or actually been denied membership of a nation state, such as stateless persons and refugees.

Membership of a nation state is, in theory, based on the self-determination of autonomous individuals. Thus, humans have come to be independent from all restrictive collectivities, including nation states, at least in theory, and in actuality from most intermediate bodies. Human rights were both a consequence and a means of bringing about such liberation. To this extent, one should see a legitimate reason for equating humans with individuals. One should also be cautious of arguments which emphasize the importance of collective rights in non-Western societies, because such arguments have often been made to rationalize violations of the rights of individuals by authoritarian governments.

However, the predominant view has thus far tended to ignore the history of 'individuals' described above, and to emphasize the essential or suprahistorical difference between the individualist West and the collectivist East. Although one cannot deny certain cultural differences between the individualist West and

\footnotetext{
${ }^{10}$ ONUMA, loc.cit.n.17 at 9. For a detailed study, see TAKAYANAGI S., 'Kindai kokka ni okeru kihonteki jinken' [Human rights in modern states], in Kihonteki Jinken no Kenkyu [Studies on human rights] Vol.1 (Tokyo Daigaku Shakai Kagaku Kenkyujo, Tokyo, 1968) 13-76; ONUMA YASUAKI., Chapter 3 on 'War', in id.(ed.), A Normative Approach to War (Oxford, 1993) at 98-121; id., Chapter 11 on 'Conclusion: Law dancing on the accompaniment of love and calculation', ibid. at 334-338, and literature cited therein, esp. O.BRUNNER, Neue Wege der Verfassungs-und Sozialgeschichte (Gottingen, 1968, trans. by ISHII S. et al., Tokyo, 1974) and P. GOUBERT, L'Ancien régime, Vol. 2 (Paris, 1973).
} 
the collectivist East, it would be wrong to explain the emphasis on collective rights by Afro-Asian intellectuals solely from [a] cultural perspective. ${ }^{101}$ Even the sketchy history of Europe with regard to individuals described above reveals that the image of the individualistic West is too simplistic and one-sided. Emphasis on collectivity by some non-Western leaders and intellectuals often represents a reaction to an excessive emphasis on individuality by some proponents of human rights who have equated individuals with humans in general.

The prevailing individual-centric view has also given the impression that 'autonomous individuals' can exist independent of nation states. Proponents of this view have not responded convincingly to the legitimate concern that excessive individual-centrism in Western societies is a major cause of the social diseases of these societies such as high crime rates and the degradation of family units and social ethics. Given the fact that this concern is widely shared even in Western societies, it is only natural that the sole emphasis on the importance of the individual cannot be persuasive. The simplistic equation of humans with individuals has worked against dealing with the suppression and cruel treatment of various categories of people within the framework of human rights. People under colonial rule, various kinds of minorities, and the collective or structural deprivation of human dignity of women, the poor, the peasants and other discriminated people have been neglected for a long time. One of the reasons why developing countries have emphasized the importance of collective rights, including the right of self-determination, is their sense of alienation in the earlier discourse on human rights. Had the notion of human rights not taken up the issue of collective deprivation of the rights of those under colonial rule, it would have been of little value to them.

A variety of factors are responsible for restricting humans to a framework of individuals for the purposes of the human rights discourse. As described earlier, the human rights mechanism was established in the process of dissolution of intermediate bodies. It was believed that the more 'liberated' from families, communities and firms, the more effectively one's human rights would be realized. The memory of the abuse of the international protection of minorities by Nazi Germany was another reason for excessive individualcentrism in human rights during the postwar period. Furthermore, the stubborn attitude of developing countries which asserted the importance of collective rights without providing theoretically solid arguments may be responsible for the consolidation of individual-centrism among Western intellectuals. It is, however, the obsession of equating humans with individuals that was, and still is, a major reason why such important issues have been barred from the mainstream treatment of human rights.

It was only after the late 1960 s that international society began to pay some attention to the collective and structural deprivation of human rights. The Tehe-

ONUMA, loc.cit.n.17 at 1-3, 8-9. 
ran Proclamation of 1968 was symbolic. Also significant in this respect was the UN General Assembly Resolution of 16 December 1977 "Alternative Approaches and Ways and Means within the United Nations System for Improving the Effective Enjoyment of Human Rights and Fundamental Freedoms". ${ }^{102}$ Although these resolutions were characterized by one-sided assertions of the developing countries in the late 1960s and 1970s, it cannot be denied that they shed light on the structural aspect of human rights, which had been ignored by the equation of a human with an individual. Further, since the 1970s the worldwide feminist movement and the movement to protect the rights of indigenous peoples have been conspicuous. The 1979 Convention on the Elimination of All Forms of Discrimination against Women was symbolic. However, the equation of humans with individuals is still deeply rooted in human rights discourse today.

As suggested earlier, there has been a tendency to regard individuals independent from families, local communities, various social institutions, and other collectivities, and to treat this separation as progressive and desirable per se. One of the serious consequences of this excessive individual-centrism is the isolation and alienation of humans now evident in many developed societies. Criticism of the notion of the unencumbered self by C. TAYLOR, A. MACINTYRE, R.BELlAH, M.GLENDON and M. SANDEL in North America is well-known. In France, another nation which has long cherished the notion of independent and autonomous individuals, the identification of humans with individuals or the emphasis upon the notion of the Cartesian self has been criticized from various perspectives. ${ }^{103} \mathrm{~A}$ call for the reconstruction of families and communities, as well as a resurgence of various kinds of religions, raise a serious question as to whether humans are strong enough to be so independent as individual-centrists claim them to be.

So long as humans are considered solely as individuals in the theory of human rights, it is difficult to deal with these questions. Moreover, movements which have achieved some success in the history of human rights are those which unite people by some particular ties: ethnicity, gender, religion, language or class. In other words, humans can effectively formulate and express their aspirations for spiritual and material well-being when they have a strong sense of belonging to some collectivity. Even in the realization of human rights, which has been understood in individualist terms, their actual aspirations and movements have taken a collective or group form. This fact must be appreciated and fully developed in the theory of human rights.

\footnotetext{
102 Loc.cit.n.92.

10. See, e.g., B.BARRET-KRIEGEL, Les droits de l'homme et le droit naturel (Paris, 1989); M.RoulanD, 'Fondements anthropologiques des droits de l'homme' (Institut International des Droits de L'Homme, vingt-quatrieme session d'enseignement, Strasbourg, 2 Juillet-30 Juillet 1993), Recueil des Cours (Strasbourg, 1993).
} 


\section{A SEARCH FOR INTERCIVILIZATIONAL HUMAN RIGHTS}

\subsection{Universalization of human rights as seen from a historical perspective}

Intercivilizational criticism of the Westcentric view of human rights does not mean endorsing the arguments of some political leaders in developing countries. Most developing countries are now in the midst of modernization. Once they had various mechanisms which, albeit insufficiently from today's perspective, could check the arbitrary use of power by rulers, such as institutionalized community member meetings and authoritative advice from elderly wise men. Modernization has substantively undermined these mechanisms, in the same way as it dissolved intermediate bodies which, to a certain extent, had checked the power of rulers in pre-modern Europe. Today, political leaders in developing countries monopolize the means of violence and can exercise it with no restraint either from pre-modern mechanisms, which have been undermined, or from modern ones, which have not yet been sufficiently established. Opposition leaders of diverse ethnic groups, clans, and linguistic or religious groups are struggling in pursuit of this almost unrestrained power. What follows are civil wars, terrorist activities and other forms of violence, with thousands of civilian casualties. This is what we have witnessed and are still witnessing in many developing countries.

The mechanism of human rights is the counterpart of the institution of modern sovereign states. It has proven to be the most effective means to protect the vital values of humans within the modern system of sovereign nation states and the capitalist economy. ${ }^{104}$ To accept the mechanism of a sovereign state, a product of modernity, and to reject that of human rights, a counter-product, is an arbitrary and convenient selection of modernity, merely pleasing power elites. If developing countries adopt the institution of sovereign states, they must also accept the mechanism of human rights. Nor can they reject human rights simply because their cultures, religions, traditions, ethics or social customs are different from those of the West. Religions and cultures in a nation change over time. Even if a nation maintains a certain religion or social ethics for a long period of time, their interpretation changes. Many cultures in nonWestern societies have already changed their character in the process of adopting modern Western ideas and institutions, such as sovereign statehood, a market economy, and an 'American way of life'. Some changes are desirable and others are not. Most are nonetheless unavoidable. Furthermore, human rights which are stipulated in major international instruments such as the ICESCR, the ICCPR and the Vienna Declaration are no longer pure Western products. They have been produced through elaborate processes whereby voices from various

${ }^{114}$ See also DoNNELLY, op.cit.n.22 at 62-65. 
nations with diverse civilizational backgrounds have been introduced, criticized, modified and amalgamated. In fact, it is the developing countries that have worked hard to introduce economic, social and cultural rights in international human rights instruments.

Developing countries emphasize the importance of human rights, particularly economic rights, on many occasions. However, these claims are often ideologies which conceal the neglect and violations of civil and political rights. Although developing countries are eager for economic development, many of them are reluctant to achieve it in the form of the realization of economic and social rights. For example, although the 1991 document Human Rights in China repeatedly claims that China regards the right to subsistence and other economic and social rights as highly significant, it mainly reiterates overall economic development, and fails to demonstrate that individuals enjoy such development as of right in an elaborate manner. ${ }^{105}$ Particularly in the area of work-related rights, the developing countries have various problems: compulsory labor in hard-labor camps, as well as in the form of debt bondage, child labor, abuse of rights to organize and collective bargaining, dishonest hiring practices, and many others. It is therefore necessary to strengthen the existing mechanisms for the implementation of economic, social and cultural rights such as the Committee on Economic, Social and Cultural Rights, and the ILO. It is also necessary to establish international and intercivilizational standards for the evaluation of human rights, including economic, social and cultural rights. By these measures, it would become possible to judge whether a certain country's claim to emphasize the importance of economic and social rights is merely an ideology concealing violations of civil and political rights, or is accompanied with sincere efforts to realize economic and social rights.

During the last few decades, many developing countries have resorted to the principle of non-intervention and claimed that human rights fall within the domain of domestic jurisdiction. It is true that the principle of non-intervention constitutes one of the fundamental principles of international law in the postwar period. According to the Declaration on Principles of International Law concerning Friendly Relations and Co-operation among States of 1970, "No State or group of States has the right to intervene, directly or indirectly, for any reason whatever, in the internal or external affairs of any other State. Consequently, armed intervention and all other forms of interference or attempted threats against the personality of the State or against its political, economic and cultural elements, are in violation of international law". ${ }^{106}$ It is also true that until the 1950s, when the international mechanism for the protection of human rights was still immature, most nations including the US regarded the problem of human rights as a domestic question.

${ }^{165}$ Loc.cit.n.94 at 8-12, 17-21.

${ }^{1: 66}$ A/RES/2625 (XXV), GAOR 25th Sess., Suppl.No.28 (A/8028) [1970]. 
However, as the PCIJ stated in its advisory opinion on the Tunisian and Moroccan Nationality Decrees case of 1923, the question of whether a certain matter is or is not solely within the jurisdiction of a State is an essentially relative question. The answer depends on the development of international relations. ${ }^{107}$ Even if the question of human rights once was in the domestic jurisdiction of a state, nations and international organizations reflecting the normative consciousness of people over the world have changed the issue from a domestic question to a matter of international concern. The UN attitude against South Africa since the 1960s, the practice of human rights committees and human rights courts based on human rights conventions and UN resolutions, beginning with the European Convention for the Protection of Human Rights of 1950 , and the UN attitude toward massive human rights violations in the former Yugoslavia, Somalia, Uganda and Haiti in the 1990s are some of the notable examples of this development. In 1993, the Vienna Declaration and Programme of Action explicitly stated that "the promotion and protection of all human rights is a legitimate concern of the international community". ${ }^{108}$ This formulation reflects the global consensus at the end of the twentieth century.

\subsection{Human rights as an effective means of realizing the spiritual and material well-being of humanity}

The intercivilizational approach to human rights seeks to analyze, understand and characterize human rights in a historical perspective, where ideas and institutions originate, develop, spread, are criticized, improved, modified and substituted. It sees in the contemporary world the simultaneous process of modernization on the part of developing nations, and a quest for post-modernity on the part of developed nations. ${ }^{10 \%}$ Based on this understanding, the intercivilizational approach to human rights shares an aim with the universalist approach: human rights should be enjoyed by people all over the world. Since the intercivilizational approach sees human rights from historical and instrumentalist perspectives, it fully admits and appreciates the historical achievement of the mechanism of human rights under the modern system of sovereign nation states and capitalist economy.

Since the time modern people created a mechanism of capitalist economy which maximizes the human desire for material well-being under the sovereign state system, they have tried various mechanisms to control these two powerful mechanisms: socialism, Marx-Lenism, anarchism, Islamism, various communes of religious believers, world federalism, and others. Some have suc-

\footnotetext{
${ }^{1 i 17}$ PCIJ Series B 1923: 24.

Vienna Declaration and Programme of Action para.4,4, loc.cit.n.96.

${ }^{1(x)}$ ONUMA, op.cit.n.6 at 192-204.
} 
ceeded in part, or, even though not successful in themselves, played a certain role in mitigating the hardship of capitalism and the sovereign state system. None has been so successful as human rights in protecting essential values and profits of humanity which may be threatened by the two systems. As I wrote elsewhere, the reason why human rights, although a particular product of modern Europe, should be universally adopted, is simple: "because we have not yet found a better alternative". 10 The intercivilizational approach therefore urges existing governments, especially those in the developing countries, to make every effort to promote and protect human rights. It is critical of the plea of domestic jurisdiction and the defence of sovereign discretion of human rights based on the particularity of culture. It differs from the universalist approach on the ways and conditions to achieve this end. Whereas the universalists assume some commonality of values to be achieved, as well as a belief in a legalistic mechanism through which such values are to be realized, the intercivilizational approach does not. Rather, it assumes the plural existence of value systems and views of humans, and seeks to integrate these differences in a discursive and dialectical manner. In sum, it is a constant quest for commonness. The intercivilizational approach characterizes human rights as a means--an extremely important means--of realizing the spiritual and material well-being of humanity. It does not regard them as an end in itself. Accordingly it is critical of the absolutism or fetishism of human rights sometimes held by human rights activists and even by academics.

The historical perspective of the intercivilizational approach also sets an important condition for the universalization of human rights. As long as the merits of the mechanism of human rights overweigh its demerits, human rights should be appreciated. Since this mechanism is a means and not an end, its usefulness and flaws must be constantly scrutinized, and its role must be complemented and substituted whenever necessary. In fact, there are various ways to direct human behaviour and to realize the well-being of humanity: the stimulation and satisfaction of material desires by the market mechanism, the threat of sanctions based on criminal and civil law, the administrative guidance, social ethics and normative consciousness based on school and family education, etc. The mechanism of human rights is one of these means.

If almost every pursuit of well-being is characterized as a human right, it would on one hand weaken the normative nature of human rights and, on the other hand, lead to a kind of absolutism of human rights. First, it would weaken the normative nature of human rights, because not all pursuits of wellbeing can appropriately be characterized as rights nor be realized by legal mechanisms. Some values such as basic knowledge for a societal life are more adequately realized by education. Other values or benefits, such as material profits, may be more effectively realized by the market mechanism. Still other values, such as affection for others, may be better attained through religion,

${ }^{116}$ ONUMA, loc.cit.n.17 at 9. 
family education, and the promotion of social ethics of communities. Pursuit of these values is not consistent with recourse to legal mechanisms.

If nonetheless such pursuit is characterized as a human right, this would not only invite doubt and criticism of the normative character of such new 'rights', but also weaken the normative nature of other existing rights for being all placed in the same category. Thus, the normativity of the entire group of human rights may be threatened. Such criticism was first raised when economic, social and cultural rights were characterized as human rights. The criticism became stronger when the notion of national self-determination was characterized as a human right, and now is directed at the notion of third generation rights. However, the reconceptualization of human rights through the incorporation of these rights on the whole has been successful. The merits of this reconceptualization are strengthening the normativity of the pursuit of economic, social and cultural well-being, as well as formulating essential aspirations of the overwhelming majority of human beings, i.e. people in the South, in terms of human rights such as the right of self-determination. These merits far exceed the demerits of weakening their normativity.

Still, the inflation of human rights raises a more serious problem: the absolutism or fetishism of human rights. The more a pursuit of well-being is characterized as a human right, the more we rely on a legalistic mechanism to realize various values and virtues. Here we must recall that the whole discourse and mechanism of human rights is a particular formulation of many ways to pursue the well-being of humanity. As such, it has its own historical and cultural qualifications. Seen from a comparative civilizational perspective, the formulation of human rights is premised on, and supported by, among other things, two major factors which are distinctively modern Western: (1) the notion of rights of independent and aggressive individuals suspicious of state authority; and (2) the adversary and legalistic system for settling social disputes, controlling state mechanisms, and realizing the interests and values of humanity. Although the significance of these factors cannot be exaggerated in protecting vital values and the interests of humans in the modern era, they also tend to produce an excessively confrontational and angular social culture. This confrontational culture is one of the major factors hampering a more harmonious and mutually trustful relationship among society members in many developed countries. ${ }^{11}$

Developing countries have been aggressive in characterizing various pursuits of their well-being as human rights. Given their underprivileged status in international society and the power of the formulation of human rights to realize aspirational values, this strategy is understandable. Furthermore, they have

11 See Glendon, op.cit.n.16; A.MACINTYRE, After virtue (Notre Dame, 1981); M.SANDEL, Liberalism and the limits of justice (Cambridge, 1982); R.BELLAH et al., Habits of the heart (Berkeley, 1985). 
been fairly successful in reconceptualizing human rights. A rigidly individualistic and legalistic character of human rights has been mitigated. Yet, so long as one characterizes the pursuit of well-being in terms of human rights, one unconsciously tends to think and behave within the framework of Westcentric modern civilization. This would hamper the many possibilities of finding an alternative or at least a complementary mechanism of human rights for pursuing various values and virtues, which is desperately needed to break the deadlock of our Westcentric modern civilization.

\subsection{Various religions and cultures could form a ground for human rights}

\subsubsection{A need for reinterpretation of religions and cultures}

The major reason for the criticism of the Westcentric universalism of human rights by non-Western, especially East Asian, nations is political, or even emotional, opposition to the self-righteous human rights diplomacy and advocacy of the West. As such, the politicized controversies over the universality versus relativity of human rights in the early 1990s were rather futile from a theoretical perspective. Yet, they played a significant role. They provided an opportunity to a larger number of people both in the North and in the South to realize that sincere intercivilizational dialogues are needed, if ever human rights are to be globalized. Furthermore, there has been an increasing amount of research dealing with diverse religions, cultures and social customs in relation to human rights, such as cross-cultural perspectives of human rights, non-Western cultural, religious or ethical bases of human rights, and the like. ${ }^{112}$ Intercivilizational frameworks of human rights may well be established in the process of such endeavors.

However, previous studies dealing with tensions between religions or cultures on one hand, and human rights on the other, have a problematic feature: a tendency to focus on non-Western religions or cultures. They seek 'cultural bases' of human rights in non-Western cultures, or 'enlightened interpretations ${ }^{113}$ of non-Western religions, so that they can be construed as compatible with the existing standards of human rights. A. AN-NA'IM's Human Rights in Cross-Cultural Perspectives is a leading example. In this excellent book, he deals with the problem of compatibility between the prohibition of cruel, inhu-

\footnotetext{
11. See, e.g., the works cited in n.20 and in ONUMA, loc.cit.n.17, at 14 ns. 9, 10. See also S.KOTHARI and H.SETHI, Rethinking human rights (Delhi, 1989); M.DAVIS (ed.), Human rights and Chinese values (Hong Kong etc., 1995); W.DE BARRY and TU W.(eds.), Confucianism and human rights (New York, 1998).

13 See, e.g., A.AN-NA'IM, 'Toward a cross-cultural approach to defining international standards of human rights', and other papers, by W.ALFORD on China, J.ZION on North American Indians, A.MCCHESNEY on Canadian aboriginal peoples, H.FRUHLING on Latin America, M.CARNERIO da CUNHA on Brazilian Indians, etc., in: AN-NA'IM, (ed.), op.cit.n.20.
} 
man or degrading treatment or punishment and punishments mandated by the Sharia. He argues that while it is impossible to abolish punishments such as the amputation of the right hand for theft, which appears cruel and inhuman to nonMuslims, it is possible to restrict its implementation in practice by resorting to an enlightened interpretation of the Sharia. By resorting to such reinterpretations of cultural values and norms, Muslim nations which give the impression that their religions and cultures are incompatible with international human rights norms can accept them. ${ }^{114}$ Similar efforts have been made by certain governments, experts and judiciaries in some non-Western countries such as India and Egypt. 115

It has been argued by a number of experts that the prevalent image of 'individualistic West versus collectivist East' is groundless. In their view, therefore, the argument based on this image that Eastern civilization is not compatible with human rights is wrong. For example, Confucianism is flexible enough to allow a liberal interpretation such as W. DE BARRY's. ${ }^{116}$ Buddhism, which has many sects or denominations, also allows for an individualistic interpretation. Japan, often regarded as a typical example of a nation of collectivism, cherished an individualistic bourgeois culture between the Muromachi and Edo periods. ${ }^{117}$

Religions and cultures in many non-Western, developing countries have been used by authoritarian governments to rationalize human rights violations, including cruel punishments, inhuman treatments and discriminatory practices. Therefore, it is understandable that earlier attempts to find religious or cultural bases of human rights have focused on the problem of the compatibility between non-Western religions or cultures and human rights. From the intercivilizational perspective, however, such an attitude is problematic. It assumes that only non-Western cultures or religions must be reinterpreted to ground human rights. In other words, it is implicitly assumed that Western cultures or religions have no problem in their compatibility with human rights. Even in ANNA'IM's book, referred to earlier, the overall emphasis is on finding out the cultural or religious basis of human rights in the non-Western world, although VIRGINIA LEARY ${ }^{18}$ and a few others seek internal discourse within Western cultures. When one looks at the prevalent understanding of human rights in some Western nations, one will notice that the above assumption must be re-

\footnotetext{
${ }^{114}$ AN-NA'IM, loc.cit.n.113 at 37-38.

11. E.COTRAN and A.O.SHERIF (eds.), The role of the judiciary in the protection of human rights (London, 1997).

1: W.DE BARRY, The liberal tradition in China (Hong Kong, 1983). See also W.DE BARRY and TU W. (eds.), op.cit.n.111.

117 YAMAZAKI M., Nihonbunka tokojinshugi [Japanese culture and individualism] (Tokyo, 1990).

"1\% V.LEARY, 'Postliberal strands in Western human rights theory', in: AN-NA'IM, op.cit.n.20 at 107.
} 
considered. For example, the US has been reluctant to embrace economic, social and cultural rights within the domain of human rights. It was not only the Republican administration of the 1980s that was hostile to treating the economic, social and cultural rights as human rights. Even NGOs and the academic community have not been so interested in them. Many people in the US have regarded them either as a socialist ideology or incompatible with civil and political rights. ${ }^{119}$ This peculiar understanding is not shared by the overwhelming majority of nations, including developed countries. While most developed countries as well as many developing countries have ratified the ICESCR, the US has not.

Reluctance in accepting international standards of human rights is not limited to the field of economic, social and cultural rights. The US was extremely late in ratifying the ICCPR. When it finally ratified it as late as 1992 (the last except for Switzerland among major developed countries), it almost nullified the Covenant as a legal instrument by attaching a package of reservations, understandings and declarations. ${ }^{120}$ Among the approximately 190 countries in international society, the US is one of the very rare countries (another conspicuous example is Somalia) which have not ratified the Convention on the Rights of the Child. Furthermore, the US does not control the possession of guns by ordinary citizens, which has resulted in a huge number of homicides as well as the killing of many criminal suspects by [the] police. ${ }^{121}$

Some of these problems may be explained in terms of opposing political ideologies or vested interests of powerful interest groups. However, cultural or religious factors are also to be held responsible. For example, 'American individualism' has often been resorted to as an important reason for the Americans to be against the idea of economic, social and cultural rights. Also, it would be difficult to understand why the US is so reluctant to control the possession of guns without taking into consideration US people's deeply-rooted belief in autonomous, independent, self-reliant and self-protective individuals. ${ }^{122}$ Thus, it is evident that we need to scrutinize these problems from a perspective of how compatible a local dominant culture is with human rights. As in Muslim nations, what is critically important is an enlightened interpretation of the dominant culture or religion which allows American people to accept the interna-

\footnotetext{
${ }^{119}$ See critical analyses by P.ALSTON, loc.cit.n.69, at 368-84. See also references in n.29.

12: For a critical analysis by an eminent US lawyer, see L.HENKIN, 'US ratification of human rights conventions', 89 AJIL (1995) 341-50.

12. See supra $\mathrm{n} .12$ and the accompanying text.

12 See the hostile opinions based on individualism and liberty-centrism cited in ALSTON, loc.cit.n.69 at 373-74, 378, 381-84.
} 
tionally established comprehensive notion of human rights. ${ }^{123}$ Such scrutiny of the tension between predominant local cultures, religions or ethics and human rights is needed in other developed countries as well.

\subsubsection{Legitimation of human rights by 'living' religions and cultures}

The attempts to ground human rights in various non-Western religions and cultures hold another problem: a tendency to revert to the original or traditional teachings of these religions and cultures. When one seeks to ground human rights in local cultures or religions, one should not explore merely traditional cultures or the original religious teachings. Cultures and religions change over time. Because of transnational economic and informational activities, no nation today preserves its religion or culture in its traditional or original form. Although Confucian culture is still an important factor in explaining the ways of thinking and behavior of Chinese, Koreans and Japanese, they are different from each other and from the original teaching of Confucius. One must explore cultures or religions which are actually 'living' in people's ordinary life.

Any major religion, including Christianity, has both pro-human rights and anti-human rights teachings in its original or traditional form. One could find certain ideas or expressions similar to those of human rights in almost all religious teachings or traditional cultures. As I claimed earlier in the context of the theory of universal origin, merely pointing out particular religious teachings or particular forms of culture as compatible with, similar to, or even an origin of particular human rights, makes little sense. ${ }^{124}$ Such sporadic references do not constitute a basis for human rights as a whole. We must explore the specific status and functions of such similar norms in comprehensive normative and societal settings. As PANIKKAR put it, ${ }^{125}$ a perspective of the homeomorphic, or existential functional, equivalent to the concept of human rights is important.

We must also seek to identify sources and methods to explore local cultures, religions and ethics to ground human rights. In the contemporary world, there are thousands of cultures and religions, ranging from world religions to cults shared by a small number of believers. What are the criteria by which we are to select important or relevant cultures, religions or ethics, and what proce-

\footnotetext{
${ }^{123}$ Another problematic feature of contemporary American culture is its universalism. To many Americans what is good for Americans must be adopted all over the world. Although I highly regard the efforts of US human rights advocates and experts to criticize and try to improve human rights conditions in their own country (see, e.g., American Civil Liberties Union \& Human Rights Watch, Human Rights Violations in the United States (New York/Washington, D.C., 1993)), it seems that some of this criticism itself is not immune from implicit US universalism.

${ }^{134}$ See supra ns.32-36 and accompanying text.

${ }^{12}$ PANIKKAR, loc.cit.n.36 at 77-78.
} 
dures are to be followed? Is the notion of unforced consensus ${ }^{126}$ a useful tool for this purpose? Can we induce some substantive criteria from the numerous cultures, religions or ethics, such as the principle of retribution tied to proportionality ${ }^{127}$ Is the notion of civilization, as shared by plural nations within a region for a certain period of time, a useful tool to limit the number of those to be selected? These questions must be explored and answered. To answer them, some people prefer to regard a certain theory as universally valid and seek to find out its view of human rights. Thus it is sometimes argued that RAWLS' theory of justice can comprehend today's fundamental normative ideas all over the world and, consequently, can claim transnational and intercivilizational legitimacy in grounding human rights which must universally be adopted. Candidates for such a privileged status could include the theories of RAWLS, DWORKIN, HARBERMAS, SEN and other leading figures. I do not believe that we could succeed in grounding human rights on a global scale by opting for one single theory of these great theorists. However capable and respected they may be, they cannot claim transnational and intercivilizational legitimacy by themselves. ${ }^{28}$ Their theories can be useful only as a means to interpret, analyze, qualify, complement and modify the existing expressions of transnational and intercivilizational human rights, i.e., existing norms in international human rights instruments.

\subsection{International human rights norms and their modification by inter- civilizational perspectives}

\subsubsection{Significance of international human rights norms}

In international law, which legally obligates states to protect and promote human rights, the international perspective is predominant. It is not so easy to find an expression of intercivilizational perspective in treaties or customary international law, the interpretation of which is often provided by judgments and advisory opinions of the ICJ. However, they are merely the sources of the rules to be applied by the ICJ (Entscheidungsnorm). If one pays attention to social norms or Handlungsregel, then one could notice an intercivilizational perspective. For example, when the UN General Assembly and the Security Council elect the members of the ICJ, the norm that "the electors shall bear in mind ... that the representation of the main forms of civilization and the principal legal systems of the world should be assured"129 has almost always been operative.

\footnotetext{
12. See C.TAYLOR, 'Conditions of unforced consensus on human rights', in: D.BELL and J.BAUER (eds.), East Asian challenges for human rights (Cambridge, forthcoming).

13 A.RENTELN, International human rights (Newbury Park, 1990) 14, 88-137.

${ }^{128}$ Among the authors I refer to in the text, only AMARTYA SEN has a certain degree of intercivilizational legitimacy because of his multi-civilizational background, knowledge and concern.

${ }^{129}$ ICJ Statute Art. 9.
} 
In practice, because the ideology of civilization prevailing at the time of the original adoption of this provision has been rejected, the election of the members of the ICJ - as well as the election of the members of the Security Council - has been accomplished by an equitable geographical distribution: three from Asia, three from Africa, five from Western Europe and others, two from Latin America, and two from Eastern Europe. Although there may be some disagreement whether the current geographical distribution is really equitable, there is a wide consensus that the election of the members in accordance with an equitable distribution is needed for such organs as the ICJ and the Security Council in order to satisfy the requirement of global legitimacy. This distribution, although characterized as geographical, is not based on purely geographical considerations. For example, the European continent is divided into East and West, the latter including North America. The concept of geographical distribution connotes political, economic, social and cultural considerations such as political and economic systems, cultures and the like. The expected role of the concept is to assure the global legitimacy of these two organs from international as well as intercivilizational perspective.

The intercivilizational perspective has played an important role in organizing an action which must appeal to people all over the world, have a high degree of its legitimacy, and be effective in its execution. For example, the military operation by the multinational forces against Iraq in 1991 enjoyed a high degree of legitimacy on a global as well as regional scale. A major reason for this success was that the US made serious efforts to persuade Arab-Muslim governments and succeeded in obtaining support transcending not only national boundaries but also civilizational boundaries. Had the support been limited to non-Muslim nations, the operation would not have had such a high degree of legitimacy and could hardly have been so successful.

In this way, although in an implicit manner, decision makers take an intercivilizational perspective whenever they take actions which must be perceived and accepted as legitimate on a global scale. This means that we could assume intercivilizational perspectives in various international behaviors and instruments. In the field of human rights, a clue to identifying intercivilizational human rights can be found in the provisions of the major international instruments on human rights to which the overwhelming majority of nations have committed themselves. The most important among these instruments constitute the socalled International Bill of Human Rights: the Universal Declaration of 1948, the ICESCR and the ICCPR. The Vienna Declaration of 1993 is also an important instrument because it embodies an international consensus on human rights at the end of the twentieth century.

From the viewpoint of international law, the multilateral human rights conventions are more important than the declarations or resolutions, because while the former formally binds contracting parties, the latter generally has only recommendatory force. Although RENTELN is right in saying that one should not easily cite ratification of human rights conventions as a basis of authority for 
human rights ${ }^{130}$, the ratification of the conventions is still extremely important in that the states which have ratified are normatively barred from making a contradicting argument against what is provided in the conventions. On the other hand, an increasing number of international lawyers hold that at least some provisions of the Universal Declaration embody norms of general international law on human rights. ${ }^{13 !}$ The Vienna Declaration is a product of heated negotiations tackling not only differences in foreign policies, but also conflicts involving the diverse religious, cultural and ethical views held by the participating states, representing almost all member nations of the international society. Unlike the Universal Declaration, which was adopted in the predecolonization era, when many Afro-Asian nations were still excluded from participation, the inter-civilizational legitimacy of the Vienna Declaration is much greater. ${ }^{132}$ Even compared with the ICESCR and the ICCPR, which have 137 and 140 contracting parties respectively (as of 1 October 1998) among which only a limited number of Asian, Muslim and Oceanian nations are included, the Vienna Declaration enjoys a higher degree of global legitimacy through its endorsement by 171 nations, including that of many Asian, Muslim and Oceanian nations.

The Vienna Declaration "reaffirms the solemn commitment of all States to fulfill their obligations to promote universal respect for, and observance and protection of, all human rights". "The universal nature of these rights and freedoms is beyond question." "Human rights ... are the birthright of all human beings." These characterizations reaffirm the universal and inherent nature of human rights. "All peoples have the right of self-determination." The right of self-determination, once doubted to be a human right because of its collectivist nature, is definitely characterized as a human right. In the framework of the purposes and principles of the UN, "the promotion and protection of all human rights is a legitimate concern of the international community". This sentence substantively denies the plea of domestic jurisdiction in the domain of human rights. "All human rights are universal, indivisible and interdependent and interrelated. The international community must treat human rights globally in a fair and equal manner, on the same footing, and with the same emphasis. While

\footnotetext{
13: A.RENTELN, 'The unanswered challenge of relativism and the consequences for human rights,' 17 Human Rights Quarterly (1985) 517.

13 Many US experts and court decisions since the Filartiga case, as well as the Restatement seek to characterize at least certain provisions of the Universal Declaration as embodying customary rules of international law and, therefore, binding on domestic courts (See articles in 25 Georgia Journal of International and Comparative Law (1995)). Some other experts, while questioning such reasoning, recognize that certain provisions can be characterized as embodying rules of general international law. See P.ALSTON and B.SIMMA, 'The sources of human rights: custom, jus cogens, and general principles', 12 Australian Year Book of International Law (1992) 105-6. See further HIGGINS, op.cit.n.22 at 18-28, 105.

13 Some Asian leaders, such as MAHATHIR of Malaysia and LI PENG of China have even suggested a critical reappraisal of the Universal Declaration because it lacks global legitimacy (Yomiuri Newspaper, 23 Aug.1997).
} 
the significance of national and regional particularities and various historical, cultural and religious backgrounds must be borne in mind, it is the duty of States... to promote and protect all human rights." These sentences exemplify the comprehensive notion of human rights, although their literal implementation is not without doubt. The Declaration also reaffirms that "the right to development is a universal and inalienable right and an integral part of fundamental human right. The human person is the central subject of development". ${ }^{133}$

The ICESCR, the ICCPR, the Vienna Declaration and other major instruments on human rights promulgated after the 1960s are no longer Western products. They are the products of long discussions, controversies and negotiations of various nations with different civilizational backgrounds. The Universal Declaration has been explicitly accepted or implicitly acquiesced by an overwhelming majority of nations since its inception. One can see behind these international instruments certain expressions of contemporary intercivilizational agreement on human rights. Whatever political motivations national governments may have had in voting for, ratifying, or acquiescing in them, these instruments now represent common normative standards based on the widest attainable consensus among nations with diverse perspectives of civilizations.

This is particularly the case with the Vienna Declaration, which was adopted by the consensus of 171 nations coming from an international community composed of independent nations representing an overwhelming majority of the human species, and adopted in a setting where some 1500 NGOs were watching and lobbying. However, it is composed of principles and does not contain specific provisions as do the Universal Declaration, the ICESCR and the ICCPR. Thus, the Vienna Declaration should be taken as containing the most authoritative - in the sense of internationally, transnationally and intercivilizationally legitimate - standards and guiding principles in interpreting, qualifying and modifying specific rules of human rights. In other words, unless the Vienna Declaration is used as the authoritative principle of interpretation, qualification and modification of the existing international human rights instruments, one cannot rebut effectively the criticism characterizing the Universal Declaration of 1948 as an expression of cultural imperialism.

\subsubsection{A need for comprehensive standards of human rights}

As described earlier, in order to carry out global human rights policies with the limited resources of our international society, we must establish human rights standards which are legitimate from international, transnational and intercivilizational perspectives, and tackle various human rights problems not on the basis of political considerations or sporadic concerns, but on priorities in terms of seriousness and urgency of the problem. Although there have been

\footnotetext{
${ }^{133}$ The Vienna Declaration and Programme of Action, loc.cit.n.96, 3-5.
} 
attempts to evaluate the conditions of civil and political rights on a global scale, few attempts have been made with regard to economic, social and cultural rights. The assessment conducted by Freedom House lacks international as well as intercivilizational legitimacy. Far more comprehensive and globally legitimate standards for the assessment of human rights must be established. In this respect, the systematic data presented by the UNDP in its annual Human Development Reports are a promising starting point.

The analyses in sections 4 and 5 have revealed that the task requires liberation from our unconscious liberty-centrism in human rights. Many data related to socio-economic rights are already available in objective figures: life expectancy, daily calory supply, infant mortality rate maternal mortality rate, femalemale gaps in life expectancy, parliament seats and managerial staffs, GDP per capita, income share of lowest $20 \%$ and highest $20 \%$ of households, literacy, mean years of schooling, primary and secondary school enrollment, and the like. They can basically be used in the assessment of how successfully nations realize economic, social and cultural rights. ${ }^{134}$ Why then, have these figures not been used thus far as relevant data in assessing human rights? One reason is theoretical or methodological difficulties in establishing reliable methods for assessing the realization of socio-economic rights through these data. ${ }^{135} \mathrm{Al}$ though such a task needs a combination of expertise in the area of human rights and in the area of development studies, economics and statistics, these areas have been studied and practiced separately from each other. It is also necessary to avoid an overestimation of quantitative methods. We need conceptual clarity of concrete economic, social and cultural rights, and disaggregate socioeconomic data for each right. One must further distinguish between factors which can be overcome by efforts of the government and those which are basically beyond the reach of human endeavors. There are other theoretical and technical problems to overcome as well.

A more critical reason for the failure seems to be the deep-rooted libertycentrism in our thinking on human rights. We have not yet developed sophisticated methods to assess the respect for and ensurance of civil and political rights. Yet, we have been accustomed to assessing them either qualitatively, as is implicitly done in the overwhelming number of cases of human rights discourse, or quantitatively, as in the case of Freedom in the World by Freedom House or World Human Rights Guide by HUMANA. It is true that a number of experts have criticized the arbitrary nature of existing assessments of human rights including these two, and have warned of the illusion of objectivity of

\footnotetext{
${ }^{134}$ See supra, ns.53-62 and accompanying text.

13 There are many studies demonstrating these difficulties. See references in n.56.
} 
quantitative methods. ${ }^{136}$ As those critiques argue we must be extremely careful in using socio-economic data as indices for measuring human rights.

On the other hand, we must avoid the trap of perfectionism. What is critically important today is to assess human rights conditions according to internationally legitimate standards with an awareness of their limitations. From this perspective, the previous discourse on this issue shares the flaws of libertycentrism. Even though people have discussed civil and political rights conditions by using unsophisticated methods, they have not discussed economic, social and cultural rights conditions by similar standards. On the other hand, when experts discuss the question of measuring the realization of economic, social and cultural rights, they tend to point out theoretical difficulties in assessing the realization of economic, social and cultural rights, and take negative attitudes in the use of socio-economic data for assessment. ${ }^{137}$ One of the serious consequences of such a state of affairs is the continuation of many arbitrary assessments of civil and political rights under the name of assessing human rights in general. If we wait to find a flawless method for assessing economic, social and cultural rights, it will hardly be possible for us to overcome the predominance of arbitrary assessment of civil and political rights under the name of human rights in general.

The failure to acknowledge socio-economic figures as important data in assessing human rights has been evident in many instances. For example, when the UNDP tried to use data in the World Human Rights Guide as indices of human freedom, they thought that they had failed to take up the problem of human rights in their previous Reports. The Human Development Report 1993 cited the criticism of the earlier human development index by stating that "[a]s a measure of human [emphasis in original] development, it is quite incomplete; it is oblivious of what is commonplace to call human rights [emphasis added]", and that "[t]he 1991 Report made an effort to remedy this omission [emphasis added] by constructing a human freedom index (HFI) based on the work of Charles Humana (1986)". ${ }^{138}$ It is true that the previous Reports did not include civil or political freedom indexes. However, this does not mean that they were oblivious of human rights. The relevant data on human rights had already been included. The UNDP had merely failed to characterize them as indices indicating - however indirectly - the realization of economic, social and cultural rights, which constitute an integral part of human rights. This failure is shared by an overwhelming majority of publications dealing with, measuring and evaluating human rights conditions. They concentrate their concern on civil and

\footnotetext{
${ }^{136}$ See, e.g., the criticism of the arbitrariness of the assessment by Freedom House, HumanA and even by experts such as GoLDSTEIN (loc.cit.n.48), and BARSH (loc.cit.n.46 at 90-114). They are especially critical of the illusion these assessments have created that one can rate civil and political rights conditions without any solid basis.

1: See e.g. the report of the seminar referred to in $n .56$.

${ }^{138}$ Human Development Report 1993 (New York/Oxford, 1993) 105.
} 
political rights, and ignore the available data relevant to economic, social and cultural rights. Thus far, controversies over the objectivity of human rights measurement have been most actively conducted in the US, where the issue has been closely linked with US human rights diplomacy. This is one of the reasons why the previous discourse had a tendency to focus on civil and political rights: the US has been most reluctant to recognize economic, social and cultural rights as human rights.

The existing international instruments on human rights represented by the ICESCR, the ICCPR, the Universal Declaration on Human Rights and the Vienna Declaration are no more than a first clue to identifying transnational and inter-civilizational human rights. They are essentially political products, generally taking the form of normative consensus among national governments. Yet, we have no other choice but to accept them as today's most authoritative expression of the normative consciousness of the global community on human rights. No other instruments, whether they be the statement by the US or Chinese government, claims of leading human rights NGOs, or views of leading scholars, can claim that they represent the global consensus more legitimately. Although we need to refine our methods in dealing with those instruments, we still have to start with them. Thus, we must operationalize the norms in these instruments in order to assess human rights conditions in all nations as today's global standard. ${ }^{139}$ If these instruments provide a comprehensive notion of human rights comprising economic, social, cultural, civil and political rights, then the standard of assessment must reflect this comprehensiveness. The same can be said of the prioritization of rights. Prioritization of human rights is an enormously difficult task, which a number of experts have discussed and yet they are far from agreeing with each other. We could, however, point out at least some perspectives that we must take into consideration when dealing with this problem. We must look into the existing international instruments on human rights, and identify the juridical significance of the right in question from the following perspectives: (1) how many states are parties to the instruments which provide for the right in question?; (2) are states parties to the conventions allowed to derogate from the protection of the right in question?; (3) is the right to be protected by states as an obligation erga omnes?; (4) is the right

\footnotetext{
${ }^{13 i}$ In a sense, the argument employed by the Chinese government in 'Human rights in China', loc.cit.n.94, is an attempt to assess human rights conditions in a comprehensive manner, i.e. including economic, social and cultural rights. However, it was not elaborate nor sophisticated, and used aggregated data without qualifications for assessing human rights.
} 
construed to be a peremptory norm?; (5) is the violation of the right characterized as an international crime?. ${ }^{140}$

The first perspective is concerned with the question whether the right should be construed as a rule of general international law. ${ }^{14}$ If the right in question is contained in resolutions or declarations of international organizations or conferences, how many nations have adopted it in domestic law, judgments of the court and other juridical forms? By answering these questions, one could assess how deeply and widely the right is established as a rule of general international law or a general principle of law. With regard to the second perspective, not all non-derogable rights are considered important. Some of them, such as the right of the family and the right to a name, are characterized as non-derogable because it is not necessary to derogate from them even in the case of emergency. Other ones, however, such as the right to life, freedom from slavery, freedom from torture and freedom from ex post punishment, which are non-derogable in the ICCPR, the European Convention for the Protection of Human Rights and the American Convention on Human Rights, are generally construed as the most basic or core human rights. ${ }^{1.2}$ The third and fourth perspectives are generally considered to be indicative of the prioritization of norms. Thus, for example, freedom from genocide and freedom from slavery are generally regarded as more important human rights than ordinary rights. ${ }^{143}$

\subsubsection{A need for critical transnational and intercivilizational perspectives}

Although one should appreciate the significance of the existing international human rights instruments, it would be too naive to ignore the political aspects of these instruments. They are products of political and diplomatic struggles and compromises between states rather than intercivilizational dialogues. For

\footnotetext{
140 As to the question of priority among human rights, see T.MERON, 'On a hierarchy of international human rights', 80 AJIL (1986) 1-23. See also S.MARKS, 'Les principes et normes des droits de l'homme applicables en period d'exception', in K.VASAK (ed.), Les dimensions internationales des droits de l'homme (Paris, 1978) 318; F.SUDRE, Droit international et européen des droit de l'homme (1989) 118; P.MEYER-BISCH, Le corps des droits de l'homme (Fribourg, 1992) 263-91; TERAYA K., Kokusai Jinken no Itsudatsu Hukanosei [The non-derogability of international human rights], Research Associate dissertation (University of Tokyo, Faculty of Law, 1997).

14: For example, although Professor SCHACHTER is critical of a hasty characterization of provisions of the Universal Declaration as norms of customary international law, he argues that some basic rights such as freedom from slavery, torture, mass murders, prolonged arbitrary imprisonment and systematic racial discrimination constitute part of customary international law. O.SCHACHTER, International law in theory and practice (Dordrecht, 1985) 335-36. Today, the general tendency is even more favourable to such a view, or an even more positive characterization of the Universal Declaration. See references in n.131.

14. TERAYA, op.cit.n.140 at 85-125.

${ }^{143}$ See references in n. 140 .
} 
example, among the four major instruments it cannot be denied that the Universal Declaration is relatively Westcentric, reflecting the international power structures existing in 1948, when many Afro-Asian nations were still under colonial rule. Since the attainment of independence, these Afro-Asian nations have emphasized the importance of collective rights and duties under the name of their traditions and cultures. Consequently, there have been references to this effect in many international human rights instruments. The right of selfdetermination of peoples in the common Article 1 of the ICESCR and the ICCPR, as well as repeated references to peoples' rights and duties of individuals in the African Charter on Human and Peoples' Rights of 1981 are notable examples.

However, the very dichotomy of 'individual versus collective' itself is a modern construct. Pre-modern people were not so concerned with this dichotomous way of thinking as we are today. It is also doubtful that pre-modern people in Asia and Africa thought so highly of the idea of duty as many AfroAsian leaders claim today. At least, the idea of legal obligation as an idea opposite to right did not occupy such a central place in East Asia as is often claimed today. For example, within the relatively less legalistic framework of Japanese culture the very way of thinking in terms of legal rights and obligations has not been predominant. It would be a fallacy to characterize 'traditional Japanese culture' as based on the concept of duties. ${ }^{14.4}$

The transnational and intercivilizational approaches seek to overcome the interstate or intergovernmental nature which 'international' undertakings often have, whether they are treaties, declarations or even controversies. From this perspective, existing international instruments on human rights are no more than a first clue to identify transnational and intercivilizational human rights. Scrutiny of these instruments from critical perspectives are needed. Although we should not idealize human rights NGOs, which tend to be self-righteous and Westcentric even in the non-Western world, their views can provide critical transnational perspectives. For example, the NGOs that participated in the final plenary of NGOs at the Vienna World Conference on Human Rights on 25 June 1993 put forward the Initial Response of Non-Governmental Organizations to the Draft Vienna Declaration. ${ }^{145}$ In it they expressed appreciation for the achievements of the World Conference such as the confirmation of human rights as a legitimate concern of the international community, the recognition of universality, indivisibility and the interdependence of human rights, the acknowledgment by the governments of the essential role of NGOs in the promotion and protection of human rights, the recognition of the rights of children and the disabled, and the reaffirmation of the right to development as a univer-

\footnotetext{
${ }^{144}$ ONUMA , loc.cit.n.17 at 3, 4, $14 \mathrm{n} .13$ and literature cited therein.

${ }^{145}$ Initial Response of Non-Governmental Organizations to the Draft Vienna Declaration, World Conference on Human Rights, Vienna, 25 June 1993.
} 
sal and inalienable human right. ${ }^{146}$ On the other hand, they were critical of the Declaration on many accounts: the refusal of the governments to address the inequality between the north and the south; the refusal of the governments to commit themselves to universal ratification of the relevant human rights conventions and the lifting of reservations by an agreed time; the insistence that the primary responsibility for standard setting lies with the states; the refusal to make a positive link between development assistance and human rights; the refusal to provide international protection against 'disappearances'; the lack of commitment to an enabling mechanism for the ICESCR; the failure to get support for the proposal to commit $0.5 \%$ of ODA to human rights; and the like.

When Asian governments gathered and adopted the Bangkok Declaration of 2 April 1993, which expressed the "aspirations and commitments of the Asian region", ${ }^{148} 110$ Asian NGOs gathered and adopted the Bangkok NGO Declaration on Human Rights of 27 March 1993. ${ }^{49}$ The former expressed a relativist or particularist perspective of human rights, stressing the respect for national sovereignty and the need to avoid double standards in the implementation of human rights, as well as the recognition of national and regional particularities and various historical, cultural and religious backgrounds. The latter, in contrast, expressed a universalist perspective, stressing the importance of women's rights, democratization of the development process and demilitarization. Thus, it is a notable example of how we might hear different opinions voiced by NGOs. The representative nature of the Bangkok Declaration must be scrutinized, and at least to a certain extent qualified by the Bangkok NGO Declaration, which commands a certain degree of transnational legitimacy.

The current international human rights instruments do not necessarily embody intercivilizational consensus based on dialogues between different civilizations. Major factors defining these instruments are those which national governments regard as national interests. Admittedly, political considerations are part of civilizations too. Even if the current international human rights instruments are a result of political compromise, they still express the agreement between nations with diverse civilizations. To this extent, they embody a global consensus which, relatively speaking, can claim not only international legitimacy but also intercivilizational legitimacy. No other view, whether it be a claim of the only super power the US, the notion of human rights held by a leading NGO such as Amnesty International, or an assertion by the Chinese government which is supported by many governments in developing countries, can claim that their view is more intercivilizationally legitimate. On the other hand, major views which embody different civilizational perspectives are im-

\footnotetext{
ist Ibid., 1-2.

14. Ibid., 2-3.

${ }^{148}$ Preamble of the Bangkok Declaration of 2 April 1993, A/CONF.157/PC/59, 14 Human Rights Law Journal (1993) 370.

14: Bangkok NGO Declaration on Human Rights, 27 March 1993, A/CONF.157/ASRM/8.
} 
portant for revising and supplementing the intercivilizational views embodied in international human rights instruments. It is here that theories of prominent experts or philosophers play an important role. These theories do not have in themselves intercivilizatioal legitimacy. However, they provide significant theoretical means with which we can analyze, construe, supplement and reformulate views expressed in the international human rights instruments from an intercivilizational perspective. For example, the concept of an overlapping consensus given by RAWLS, ${ }^{150}$ or the concept of an unforced consensus suggested by TAYLOR, ${ }^{151}$ might provide a theoretical framework with which we could clarify the nature and meaning of consensus in the instruments. On the other hand, we should always bear in mind that these great figures have often unconsciously created their theories within Westcentric frameworks.

The inter-civilizational perspective is based on the idea that international perspectives are not enough to understand global issues. A person with rich international perspectives does not necessarily grasp global issues because his/her 'international' perspectives may be limited to a certain civilization. For example, even if one understands English, French, German and Spanish cultures and/or languages, and has [a] deep knowledge OF PLATO, ARISTOTLE, Thomas Aquinas, HobBes, Lock, Rousseau, AdAm SMith, MaX Weber AND KARL MARX, one may lack even an elementary knowledge of Islam, East Asian or South Asian civilization including Sharia, Buddhism, Confucianism and Hinduism. The intercivilizational approach seeks to overcome such narrowness. ${ }^{152}$

When we consider the problem of human rights from an inter-civilizational perspective, we must ask whether the right in question is prescribed in, endorsed by, or at least construed to be compatible with, the precepts of today's major religions, ${ }^{153}$ and whether we can find an equivalent norm among major legal systems or social ethics transcending civilizational boundaries. It is certainly wrong to claim that a nation cannot accept human rights simply because they are incompatible with national culture. Cultures change over time. However, this argument is also valid in the universalist or liberty-centrist view of human rights. If culture changes over time, then the notion of human rights changes as well. It is self-contradictory for a universalist to criticize a relativist's argument based on national culture, by arguing that cultures change, and yet stick to a narrow, liberty-centric notion of human rights. Such a notion may

\footnotetext{
${ }^{19 .}$ J.RAWLS, Political liberalism (New York, 1993).

15: TAYLOR, loc.cit.n.126.

ONUMA, op.cit.n.6 at 20-49. See also ONUMA, loc.cit.n.21.

${ }^{153}$ The Cairo Declaration on Human Rights in Islam, adopted 5 August 1990 in Cairo, is primarily an international instrument based on the agreement of Muslim states, i.e. Muslim governments. This Declaration should be considered as an important source for the pursuit of an inter-civilizationally legitimate notion of human rights. Similar instruments based on agreement among Christians, Buddhists and adherents of other major religions should also be taken into consideration.
} 
have been valid in the past, but it is evident that the notion of human rights does change. One would fool oneself if one were to assert that only the notion of human rights is unchangeable. Consequently, the intercivilizational approach requires us to see the problem of human rights from the perspective of the plurality of current civilizations as well as their changeability.

The constant scrutiny and reconceptualization of the notion of human rights as exemplified by the incorporation and substantiation of economic, social and cultural rights, the right of self-determination of peoples, and the right to development should liberate us from liberty-centrism as a persistent form of Westcentrism, as well as from the fetishism of human rights. At the same time, the reconceptualization of human rights will help persuade developing countries to accept human rights in their countries, because the reconceptualization of human rights is possible only on the basis of the agreement of an overwhelming majority of the global community, including developing countries. This double function of liberating human rights discourse from predominant Westcentrism, and spreading human rights on a global scale, is what the intercivilizational approach searches for. By accumulating similar efforts, it can contribute to grounding human rights in more diverse societies, as well as qualifying human rights discourse in its proper range. This is why we need the intercivilizational approach in this diverse and changing world of modernity and postmodernity. ${ }^{1.54}$

${ }^{154}$ For a detailed study, see ONUMA, op.cit.n.13 at 279-335. 